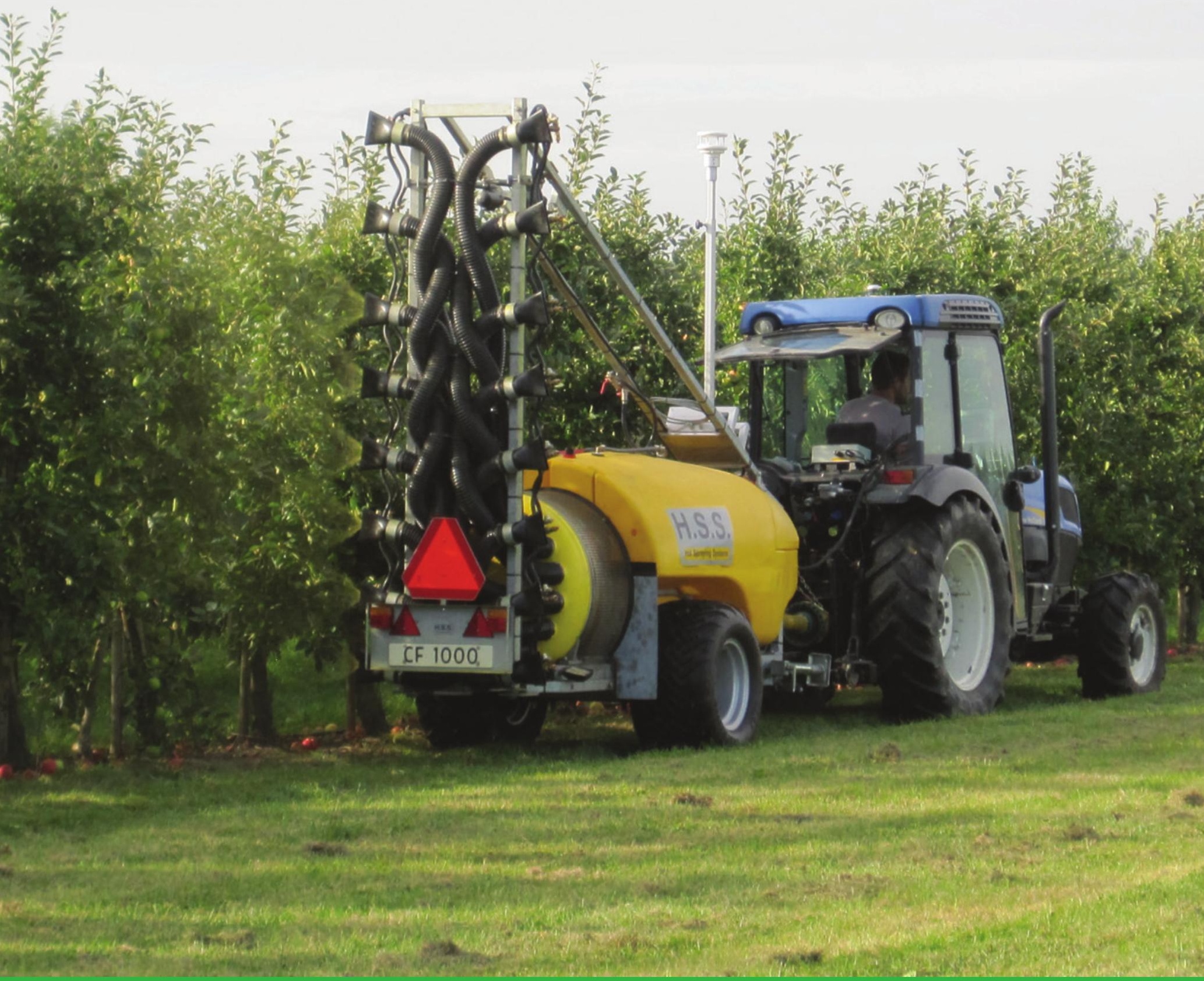

\title{
Driftreductie H.S.S. CF boomgaardspuit met blaasmondverstelling en lage luchthoeveelheid
}





\section{Driftreductie H.S.S. CF boomgaardspuit met blaasmondverstelling en lage luchthoeveelheid}

H. Stallinga, P. van Velde, J.M.G.P. Michielsen, M. Wenneker \& J.C. van de Zande

Dit onderzoek is in opdracht van Hol Spraying Systems (H.S.S., Meteren) uitgevoerd door de Stichting Wageningen Research (WR), business unit Agrosysteemkunde, in het kader van onderzoek naar de driftreductie van de H.S.S. CF boomgaardspuit (projectnummer 3710444800).

WR is een onderdeel van Wageningen University \& Research, samenwerkingsverband tussen Wageningen University en de Stichting Wageningen Research.

Wageningen, maart 2017

Rapport WPR-675 
Stallinga, H., P. van Velde, J.M.G.P. Michielsen, M. Wenneker \& J.C. van de Zande, 2017. Driftreductie H.S.S. CF boomgaardspuit met blaasmondverstelling en lage luchthoeveelheid. Wageningen Research, Rapport WPR-675. 50 blz.; 12 fig.; 15 tab.; 25 ref.

Dit rapport is gratis te downloaden op https://doi.org/10.18174/419913

Results of spray drift experiments are reported of the H.S.S. CF crossflow fan sprayer. The H.S.S. CF is equipped with a H.S.S. Drift Control system and a H.S.S. Automatic Wind Control (AWC) system to adjust and control air fan speed and the air spout direction based on measured wind direction. When spraying against the wind the air spouts are set rectangle to the driving direction and downwind in an backwards angle giving less air support through tree leaf canopy. The H.S.S. CF equipped with Drift Control and AWC, equipped with $90 \%$ drift reducing nozzles and utilizing a lower level of air assistance (1800 rpm fan) obtains a spray drift reduction of $90.6 \%$ at $4 \frac{1}{2}-51 / 2 \mathrm{~m}$ distance from the last tree row compared to the reference spray system for fruit crop spraying in the Netherlands although the outside row of the orchard is sprayed from both sides. When the outside tree row is sprayed only from the outside this H.S.S. CF combination and adapted air spout direction (H.S.S. AWC) obtains a $95.0 \%$ spray drift reduction at $4 \frac{1}{2}-5 \frac{1}{2} \mathrm{~m}$ distance from the last tree row.

Measurement of airborne spray drift averaged over 0-10 m height at 7.5 m distance from the last tree row resulted in a spray drift reduction of $94.4 \%$ when spraying with the H.S.S. CF equipped with Drift Control, $90 \%$ drift reducing nozzles and utilizing a lower level of air assistance (1800 rpm fan) and two-sided spraying of the outside tree row. Using these settings of the H.S.S. CF in combination with automatic air spout direction of H.S.S. AWC and one sided spraying of the outside tree row resulted in $92.1 \%$ reduction of airborne spray drift.

Key words: orchard sprayer, spray drift, nozzle type, air assistance, spray drift reduction

(c) 2017 Wageningen, Stichting Wageningen Research, Wageningen Plant Research, Business unit Agrosysteemkunde, Postbus 16, 6700 AA Wageningen; T 03174807 00; www.wur.nl/plant-research

KvK: 09098104 te Arnhem

VAT NL no. 8113.83.696.B07

Stichting Wageningen Research. Alle rechten voorbehouden. Niets uit deze uitgave mag worden verveelvoudigd, opgeslagen in een geautomatiseerd gegevensbestand, of openbaar gemaakt, in enige vorm of op enige wijze, hetzij elektronisch, mechanisch, door fotokopieën, opnamen of enige andere manier zonder voorafgaande schriftelijke toestemming van Stichting Wageningen Research.

Stichting Wageningen Research is niet aansprakelijk voor eventuele schadelijke gevolgen die kunnen ontstaan bij gebruik van gegevens uit deze uitgave.

Rapport WPR-675

Foto omslag: Jan van de Zande (HSS-CF-drift-zande-IMG_7841.JPG) 


\section{Inhoud}

Woord vooraf $\quad 5$

$\begin{array}{ll}\text { Samenvatting } & 7\end{array}$

$\begin{array}{ll}\text { Summary } & 9\end{array}$

$1 \quad$ Inleiding $r$

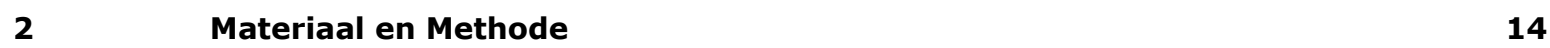

$\begin{array}{lll}2.1 & \text { Afstelling en beschrijving spuittechniek } & 14\end{array}$

2.1.1 Karakteristieken Munckhof standaard boomgaardspuit $\quad 14$

2.1.2 Karakteristieken H.S.S. CF dwarsstroomspuit $\quad 15$

2.1.3 Samenvatting gebruikte spuittechnieken 18

2.2 Beschrijving metingen en verwerking resultaten $\quad 18$

2.2.1 Metingen 18

2.2.2 Analyses 19

$\begin{array}{ll}2.2 .3 \text { Berekeningen en statistiek } & 19\end{array}$

$\begin{array}{lll}2.3 & \text { Weersomstandigheden } & 21\end{array}$

$\begin{array}{llr}3 & \text { Resultaten } & 23\end{array}$

3.1 Drift naar de grond naast het perceel $\quad 23$

$\begin{array}{ll}3.1 .1 \mathrm{HSS}-\mathrm{CF}-\mathrm{A} & 23\end{array}$

$\begin{array}{ll}3.1 .2 \text { HSS-CF -B en HSS-CF -C } & 24\end{array}$

$\begin{array}{lll}3.2 & \text { Drift naar de lucht } & 27\end{array}$

$\begin{array}{ll}3.2 .1 \text { HSS-CF -A } & 27\end{array}$

$\begin{array}{ll}3.2 .2 \text { HSS-CF -B en HSS-CF -C } & 28\end{array}$

$\begin{array}{llr}4 & \text { Discussie } & 31\end{array}$

$\begin{array}{llr}5 & \text { Conclusie } & 34\end{array}$

Literatuur $\quad 35$

$\begin{array}{lll}\text { Bijlage } 1 & \text { Script statistische analyse } & 37\end{array}$

Bijlage 2 Weersomstandigheden tijdens driftmetingen 38

Bijlage 3 Driftdepositie (\% van afgifte) op de grond naast het gewas 41

Bijlage 4 Driftdepositie (\% van afgifte) naar de lucht 46

Bijlage 5 Achtergrond informatie lijst TCT adviezen en driftarme spuitdoppen 



\section{Woord vooraf}

De emissie van gewasbeschermingsmiddelen verminderen is van groot belang voor de fruitteelt en speelt een belangrijke rol bij de invulling van beleid en regelgeving. Toedieningstechnieken die de drift, het verwaaien van de spuitvloeistof tot buiten het doelgewas, reduceren zijn nodig om de beleidsdoelen te kunnen realiseren en om gewasbeschermingsmiddelen veilig te kunnen gebruiken. In deze rapportage wordt het onderzoek van een driftreducerende techniek in de fruitteelt beschreven. Drift onderzoek is gedaan aan de H.S.S. CF boomgaardspuit met een H.S.S. Drift Control systeem en een H.S.S. Automatic Wind Control (AWC) systeem met gebruikmaking van een $90 \%$ driftreducerende spuitdop en lage luchtondersteuning (1800 rpm ventilator) in het volblad stadium van een appelboomgaard. De driftmetingen zijn uitgevoerd in het drift proefveld voor de fruitteelt, een boomgaard van Wageningen UR WPR-Fruit te Randwijk, met medewerking van Wageningen UR Unifarm.

Dit onderzoek is uitgevoerd in opdracht van Hol Spraying Systems en begeleid door dhr. $\mathrm{H}$. Hol (H.S.S., Meteren).

Wageningen, Maart 2017 


\section{Samenvatting}

Met de H.S.S. CF boomgaardspuit met automatische blaasmondverstelling zijn door Wageningen UR volgens standaard meetprotocol (CIW en ISO22866) driftmetingen uitgevoerd in vergelijking met de referentie spuit zoals in Nederland gebruikt (Munckhof dwarsstroom met Albuz met ATR lila en 7 bar spuitdruk). De driftmetingen zijn in het groeiseizoen 2016 (september - november 2016) in drie perioden uitgevoerd bij de bespuiting van de buitenste 8 rijen $(24 \mathrm{~m}$ ) van een appelboomgaard. De driftmetingen zijn uitgevoerd in de volblad situatie (BBCH90) van de boomgaard. De H.S.S. CF was tijdens de driftmetingen uitgerust met 90\% driftreducerende spuitdoppen (Albuz TVI8001 bij 7 bar spuitdruk) en was ingesteld op een lage luchtopbrengst van de ventilator (1800 rpm ventilator) welke geregeld en vastgelegd werd door de H.S.S. Drift Control box. Door de constructie van de spuit zuigt de ventilator geen spuitvloeistof aan en blaast daardoor aan de zijde waar niet gespoten wordt geen spuitvloeistof uit. De overige gebruikte instellingen van de H.S.S. CF tijdens de driftmetingen waren: 2-zijdig spuiten buitenste bomenrij, 1-zijdig spuiten buitenste bomenrij, 1-zijdig spuiten buitenste bomenrij + automatische instelling van de blaasmonden afhankelijk van de windsnelheid en richting. De instelling van de blaasmonden wordt automatisch volgens een rekenregel in de H.S.S. AWC (Automatic Wind Control) box gestuurd op basis van een sensor op de spuit die de windsnelheid en richting meet.

De resultaten van de driftmetingen zijn gebruikt voor het indelen van de H.S.S. CF met lage lucht instelling (1800 rpm ventilator) zoals ingesteld op de H.S.S. Drift Control box en in combinatie met de automatische blaasmond verstelling met de H.S.S. AWC in een driftreductieklasse. Voor de indeling in een driftreductieklasse is de driftdepositie op 4,5-5,5 $\mathrm{m}$ van de laatste bomenrij gebruikt in vergelijking met die van de referentie bespuiting.

De resultaten van de driftmetingen leiden tot de volgende driftreductie voor de verschillende instellingen van de H.S.S. CF:

- H.S.S. CF serie uitgevoerd met H.S.S. Drift Control met lage lucht instelling (1800 rpm ventilator) en 2-zijdig spuiten van de buitenste bomenrij met $90 \%$ driftreducerende spuitdop (TVI8001 op 7 bar) geeft 90,6\% driftreductie;

- H.S.S. CF serie uitgevoerd met H.S.S. Drift Control met lage lucht instelling (1800 rpm ventilator) en eenzijdig spuiten van de buitenste bomenrij met 90\% driftreducerende spuitdop (TVI8001 op 7 bar) geeft 92,2\% driftreductie;

- H.S.S. CF serie uitgevoerd met H.S.S. Drift Control en H.S.S. AWC (Automatic Wind Control) met lage lucht instelling (1800 rpm ventilator) en eenzijdig spuiten van de buitenste bomenrij met $90 \%$ driftreducerende spuitdop (TVI8001 op 7 bar) en automatische hoekverdraaiing van de spuitmonden geeft $95.0 \%$ driftreductie.

De H.S.S. CF kan met bovengenoemde instellingen ingedeeld worden in respectievelijk de Drift Reducerende Techniek (DRT) klassen DRT90, DRT90 en DRT95.

Op grond van de onderzoeksresultaten van de H.S.S. CF boomgaardspuit zal met doptypen uit andere driftreducerende dop klassen (DRD 50\%, 75\%, 95\%) dan onderzocht (DRD 90\%) de buitenste bomenrij ook tweezijdig gespoten kunnen worden terwijl de driftreductie van die driftreducerende dopklasse gehaald wordt. In combinatie met de AWC zal bij eenzijdig spuiten van de buitenste bomenrij en gebruik van driftreducerende doppen uit de klassen DRD 50\% en DRD 75\% zal de driftreductie overeenkomstig de DRT klassen 75 en 90 zijn, één DRT klasse hoger dan de gebruikte DRN klasse van de spuitdop. Bij gebruik van DRD 95\% spuitdoppen en AWC wordt in combinatie met een 4,5 m teeltvrije zone een driftreductie van $97,5 \%$ gehaald.

De driftreductie naar de lucht, gemiddeld over 0-10 m hoogte, op 7,5 $\mathrm{m}$ van de laatste bomenrij is voor de H.S.S. CF serie uitgevoerd met H.S.S. Drift Control met lage lucht instelling (1800 rpm ventilator) en 2-zijdig spuiten van de buitenste bomenrij met $90 \%$ driftreducerende spuitdop (TVI8001 op 7 bar) $94,4 \%$. Met deze combinatie en eenzijdig spuiten van de buitenste bomenrij is een driftreductie naar de lucht gevonden van 93,3\%. Bij eenzijdig spuiten van de buitenste bomenrij met deze combinatie met gebruikmaken van automatische hoekverdraaiing van de spuitmonden met H.S.S. AWC (Automatic Wind Control) is een driftreductie naar de lucht van 92,1\% gevonden. 


\section{Summary}

With the H.S.S. CF orchard sprayer and variable air spout setting Wageningen UR performed spray drift experiments following the Dutch CIW and ISO22866 protocols. Measurements were done in comparison with a reference spray technique (Munckhof cross-flow fan sprayer with Albuz ATR lilac nozzles at 7 bar spray pressure). Spray drift experiments were done in the 2016 growing season (September - November 2016) spraying the downwind 8 rows of an apple orchard. Applications were done in three periods in the full leaf stage of the apples (BBCH90). The H.S.S. CF was equipped with $90 \%$ drift reducing nozzles (Albuz TVI8001 at 7 bar spray pressure) and the air assistance was set in a low setting using the fan at $1800 \mathrm{rpm}$. Fan speed was controlled and recorded by the H.S.S. Drift Control box. Because of the construction of the sprayer the fan does not take up any spray liquid and does not blow it out at the side where the nozzles are switched off.

Spray drift experiments were done to compare: spraying the outside tree row from both sides, spraying the outside tree row only from the outside, and spraying the outside tree row only from the outside in combination with the automatic setting of the air spout direction using the algorithms in the H.S.S. AWC (Automatic Wind Control) box depending on wind speed and direction during the measurements.

Results of the spray drift experiments are used to quantify spray drift reduction of the H.S.S. CF with low air setting (1800 rpm fan) as set with the H.S.S. Drift Control box and in combination with the automatic setting of the air spout direction using the H.S.S. AWC (Automatic Wind Control) box. To quantify the spray drift reduction the spray drift deposition at 4.5-5.5 $\mathrm{m}$ from the last tree row of the H.S.S CF and its settings is evaluated against the spray drift deposition of the reference spray technique.

The results of the spray drift experiments lead to the following spray drift reductions of the different settings of the H.S.S. CF sprayer:

- H.S.S. CF series equipped with H.S.S. Drift Control and low air setting (fan $1800 \mathrm{rpm}$ ) and 2-sided spraying of the outside tree row and $90 \%$ drift reducing nozzles (TVI8001 at 7 bar) gave a 90,6\% spray drift reduction;

- H.S.S. CF series equipped with H.S.S. Drift Control and low air setting (fan $1800 \mathrm{rpm}$ ) and 1-sided spraying of the outside tree row and $90 \%$ drift reducing nozzles (TVI8001 at 7 bar) gave a 92,2\% spray drift reduction;

- H.S.S. CF series equipped with H.S.S. Drift Control and H.S.S. AWC (Automatic Wind Control) and low air setting (fan $1800 \mathrm{rpm}$ ) and 1-sided spraying of the outside tree row and $90 \%$ drift reducing nozzles (TVI8001 at 7 bar) and automatic adaptation of the air spout direction gave a 95.0\% spray drift reduction.

The H.S.S. CF can for the above mentioned settings be classified in respectively the spray Drift Reducing Technology (DRT) classes DRT90, DRT90 en DRT95.

Based on the results presented it can be reasoned that similar effects will occur with nozzles from other spray drift reduction classes (DRN 50\%, 75\%, 95\%) than measured (DRN 90\%). With use of the H.S.S. CF sprayer and Drift Control (1800 rpm fan) two sided spraying of the outside row will lead to a spray drift reduction level as of the implemented drift reduction class of the nozzle. With aid of the AWC and one-sided spraying of the outside row and DRN 50\% and DRN 75\% class nozzles the DRT class will be respectively DRT75 and DRT90, one class higher than the implemented DRN class nozzle. With use of a DRN 95\% nozzle in combination with a crop-free buffer zone of 4,5 m spray drift reduction will be $97,5 \%$.

Measurement of airborne spray drift averaged over 0-10 m height at 7.5 m distance from the last tree row resulted in a spray drift reduction of $94.4 \%$ when spraying with the H.S.S. CF equipped with Drift Control, $90 \%$ drift reducing nozzles and utilizing a lower level of air assistance (1800 rpm fan) and two-sided spraying of the outside tree row. Using these settings of the H.S.S. CF in combination with one sided spraying of the outside tree row resulted in $93.3 \%$ reduction of airborne spray drift. Using these settings of the H.S.S. CF in combination with automatic air spout direction of H.S.S. AWC and one sided spraying of the outside tree row resulted in $92.1 \%$ reduction of airborne spray drift. 


\section{$1 \quad$ Inleiding}

De emissie van gewasbeschermingsmiddelen verminderen is van groot belang voor de fruitteelt (VW et al., 2000) en speelt een belangrijke rol bij de invulling van Duurzame Gewasbescherming (LNV, 2004; EZ, 2013), het Activiteitenbesluit Milieubeheer (I\&M, 2012) en de toelating van gewasbeschermingsmiddelen (Ctgb, 2016). Een van de doelstellingen van het Meerjarenplan Gewasbescherming (MJPG, 1991) was de vermindering van de uitstoot van gewasbeschermingsmiddelen. Deze uitstoot naar oppervlaktewater zou in 2000 met tenminste $90 \%$ teruggebracht moeten zijn. Uit metingen van waterkwaliteitsbeheerders bleek dat de concentraties van gewasbeschermingsmiddelen de normen regelmatig overschreden. Om piekbelastingen van het oppervlaktewater tegen te gaan en $90 \%$ emissiereductie te realiseren, is per 1 maart 2000 het Lozingenbesluit open teelt en veehouderij van kracht geworden, een onderdeel van de Wet verontreiniging Oppervlaktewater (VW/VROM/LNV, 2000, 2007). De aanpassing van het LOTV in 2007 leidde voor de fruitteelt tot pakketten van maatregelen met minimaal $90 \%$ driftreductie wanneer bespuitingen langs oppervlaktewater uitgevoerd werden. Deze pakketten van maatregelen zijn bij de invoering van het Activiteitenbesluit Milieubeheer (I\&M, 2012) voor bespuitingen in de fruitteelt overgenomen. Door implementatie van de tweede nota Duurzame Gewasbescherming (EZ, 2013) zal op alle percelen de toediening van gewasbeschermingsmiddelen met minimaal $75 \%$ driftreducerende technieken (DRT) uitgevoerd moeten worden.

Daarnaast is ook bij de toelating van gewasbeschermingsmiddelen de driftdepositie op wateroppervlak van belang. Het College voor de Toelating van Bestrijdingsmiddelen en Biociden (Ctgb) neemt beslissingen, onder andere op basis van de inschatting van de effecten op het milieu (Ctgb, 2014). Hierbij is het nodig te weten hoeveel van het middel in het oppervlaktewater terecht komt. Het Ctgb heeft de resultaten van emissie-onderzoek (Huijsmans et al., 1997; Zande et al., 2001, 2007, 2012; Wenneker et al., 2004, 2014; Stallinga et al., 2011a, 2011b, 2013, 2016) opgenomen in een drifttabel (Ctgb, 2016). In Tabel 1.1 is voor een aantal technieken zoals gebruikt in de fruitteelt de driftreductieklasse en de driftdepositie weergegeven.

Tabel 1.1 Driftdepositie (\%) op wateroppervlak (5 $m$ vanaf buitenste bomenrij) van driftreducerende technieken (DRT)in verschillende driftreductieklassen in de kale boom (voor 1 mei) en de volblad (na 1 mei) situatie (naar: Ctgb, 2016).

\begin{tabular}{|c|c|c|}
\hline \multirow[t]{2}{*}{ Driftreducerende techniek groot fruit } & \multicolumn{2}{|c|}{ Driftpercentage [\%] } \\
\hline & Kaal & Volblad \\
\hline Standaard & 16,6 & 8,6 \\
\hline Éénzijdig spuiten laatste bomenrij & 9,8 & 4,7 \\
\hline Standaard $+9 \mathrm{~m}$ teeltvrije zone & 3,6 & 2,7 \\
\hline \multicolumn{3}{|l|}{ DRT50: } \\
\hline Sensorgestuurde bespuiting & 12,8 & 4,1 \\
\hline Dwarsstroomspuit met reflectiescherm & 7,5 & 3,9 \\
\hline \multicolumn{3}{|l|}{ DRT75: } \\
\hline Tunnelspuit & 2,5 & 1,3 \\
\hline KWH k1500-3R2 VLOS 3-rijen spuit + standaard doppen & 8,3 & 1,7 \\
\hline \multicolumn{3}{|l|}{ DRT90: } \\
\hline $90 \%$ driftreducerende dop + éénzijdige bespuiting laatste bomenrij & 2,5 & 1,0 \\
\hline KWH Mistal VLBS + 90\% driftreducerende dop (540 rpm pto) & - & 0,75 \\
\hline \multicolumn{3}{|l|}{ DRT95: } \\
\hline $\begin{array}{l}\text { KWH k1500-3R2 VLOS 3-rijen spuit + variabele luchtondersteuning }+90 \% \\
\text { driftreducerende doppen }\end{array}$ & 0,70 & 0,43 \\
\hline $\begin{array}{l}\text { KWH k1500-3R2 VLOS 3-rijen spuit }+ \text { variabele luchtondersteuning }+90 \% \\
\text { driftreducerende doppen }+400 \text { rpm aftakas }\end{array}$ & 0,65 & 0,05 \\
\hline
\end{tabular}


De emissie van gewasbeschermingsmiddelen in de fruitteelt is hoog ten opzichte van andere teeltsectoren. Dit wordt ondermeer veroorzaakt door de opgaande en horizontale spuitrichting en de vaak krachtige luchtondersteuning bij fruitteeltspuiten waardoor veel spuitvloeistof door het bladerdek van de bomenrijen heen gespoten wordt. Om drift te beperken zijn verschillende techniek- en teeltmaatregelen mogelijk. Technische maatregelen kunnen bestaan uit doptype, afscherming en luchtondersteuning. Een teeltmaatregel is bijvoorbeeld het aanleggen van een windsingel (windhaag), of het aanleggen van een teeltvrije zone waardoor de afstand tussen het te bespuiten gewas en het oppervlaktewater vergroot wordt, en de drift naar het wateroppervlak af zal nemen.

Emissie naar de lucht (druppels en damp) bij gewasbespuitingen wordt in de toelating van middelen of het Activiteitenbesluit Milieubeheer momenteel niet in ogenschouw genomen. Uit metingen is gebleken dat bespuitingen met neveldoppen een aanzienlijke drift naar de lucht tot gevolg kunnen hebben (Michielsen et al., 2007, Zande et al., 2014). Deze emissie kan relevant zijn voor milieubelasting op grotere afstand van percelen, of consequenties hebben voor de aanwezigheid van bijvoorbeeld omwonenden en bebouwing (Gezondheidsraad, 2014).

Het Activiteitenbesluit Milieubeheer (AM, voorheen LOTV) bevat voorschriften die onder andere een beperking van de emissies van gewasbeschermingsmiddelen en nutriënten naar oppervlaktewater bewerkstelligen. Het AM staat toe dat degene die agrarische activiteiten uitvoert, ook andere methoden toe kan passen mits aangetoond kan worden dat tenminste een gelijkwaardige bescherming van het oppervlaktewater wordt bereikt als met het eindpakket. Het eindpakket bevat combinaties van spuittechnieken, aanvullende maatregelen en teeltvrije zones zoals bedoeld onder artikel 3.80 van het AM.

Als basismaatregel geldt voor de fruitteelt dat de teeltvrije zone naast watergangen 9 meter is wanneer gebruik gemaakt wordt van een standaard spuittechniek. Deze teeltvrije zone kan smaller zijn als er extra maatregelen worden toegepast om drift te beperken. Momenteel zijn er naast de 9 meter teeltvrije zone nog 6 maatregelen erkend waarmee aan het AM voldaan kan worden. Een van de maatregelen is het spuiten met $90 \%$ driftreducerende doppen, in combinatie met enkelzijdig spuiten van de buitenste bomenrij. Naar aanleiding van onderzoek naar dopclassificatie naar driftreductie in de fruitteelt (Zande et al., 2007; Stallinga et al., 2011a, 2011b) is deze maatregel alleen toegestaan voor axiaal- of dwarsstroomspuit met $90 \%$ of $95 \%$ driftreducerende spuitdoppen in combinatie met een $3 \mathrm{~m}$ teeltvrije zone. Voor Axiaal- of dwarsstroomspuit met $50 \%$ of $75 \%$ driftreducerende spuitdoppen moet een 4,5 m teeltvrije zone aangehouden worden (TCT, 2016).

Door fruittelers is aangegeven dat het eenzijdig spuiten van de buitenste bomenrij bezwaren heeft in verband met de effectiviteit van de middelen en de bladbedekking van de bespuiting. Men geeft de voorkeur aan de buitenste bomenrij van twee zijden spuiten. Door gebruik te maken van $90 \%$ driftreducerende spuitdoppen verlaagde luchthoeveelheid en aanpassing van de luchtrichting afhankelijk van de heersende windrichting is voor 3-rijen spuiten (Stallinga et al, 2013, Wenneker et al., 2014) aangetoond dat dit kan. H.S.S. heeft daarom een enkelrij dwarsstroom spuit ontwikkeld, de H.S.S. CF met H.S.S. Drift Control en H.S.S. Automatic Wind Control (AWC), die met een sensor de windrichting meet en aan de hand daarvan de richting van de spuitmonden van de luchtondersteuning links en rechts aanpast. Het principe van dit systeem is dat er tegen de wind in meer luchtondersteuning gegeven wordt en met de wind mee minder luchtondersteuning. Door de H.S.S. CF met H.S.S. Drift Control uit te rusten met $90 \%$ driftreducerende spuitdoppen en gebruik te maken van een lage luchthoeveelheid bij $1800 \mathrm{rpm}$ van de ventilator wordt verwacht dat de driftreductie $90 \%$ kan zijn terwijl de buitenste bomenrij wel van twee zijden bespoten wordt. Wordt daarbij ook het H.S.S. AWC systeem gebruikt, voor gescheiden aanpassing van de richting van luchtondersteuning in de bovenwindse en benedenwindse richting, dan wordt verwacht dat de driftreductie meer dan $95 \%$ zal zijn. Om deze verwachting te onderbouwen is door H.S.S. driftonderzoek uitgevoerd.

\section{Doel van het onderzoek}

Vergelijking van de spuitdrift van de H.S.S. CF boomgaardspuit met H.S.S. Drift Control met $90 \%$ driftreducerende doppen en aangepaste hoeveelheid luchtondersteuning en in combinatie met H.S.S. Automatic Wind Control (AWC) en een standaard dwarsstroom boomgaardspuit (Huijsmans et al., 1997). De driftmetingen worden dusdanig opgezet dat resultaten voldoen aan de opgestelde eisen vanuit de toelating van gewasbeschermingsmiddelen (Ctgb), het Activiteitenbesluit Milieubeheer (CIW, 
2003) en internationale afspraken rondom erkenning van driftmetingen (ISO22866, 2005;

ISO22369,2006).

In deze rapportage worden de uitgevoerde driftmetingen van de H.S.S. CF boomgaardspuit met H.S.S. Drift Control en H.S.S. Automatic Wind Control (AWC) en de standaard dwarsstroom boomgaardspuit tijdens bespuitingen van een appelboomgaard in het volblad (na 1 mei) stadium beschreven. In hoofdstuk 2 wordt de proefopzet besproken, daarna volgen in hoofdstuk 3, 4 en 5 respectievelijk de resultaten, discussie en conclusies. 


\section{Materiaal en Methode}

\subsection{Afstelling en beschrijving spuittechniek}

In een veldonderzoek is in 2016 de drift vastgelegd van een H.S.S. CF dwarsstroomspuit bij 3 verschillende instellingen:

- H.S.S. CF serie uitgevoerd met H.S.S. Drift Control met lage lucht instelling (1800 rpm ventilator) en 2-zijdig spuiten van de buitenste bomenrij met 90\% driftreducerende spuitdop (TVI8001 op 7 bar);

- H.S.S. CF serie uitgevoerd met H.S.S. Drift Control met lage lucht instelling (1800 rpm ventilator) en eenzijdig spuiten van de buitenste bomenrij met $90 \%$ driftreducerende spuitdop (TVI8001 op 7 bar);

- H.S.S. CF serie uitgevoerd met H.S.S. Drift Control en H.S.S. AWC (Automatic Wind Control) met lage lucht instelling (1800 rpm ventilator) en eenzijdig spuiten van de buitenste bomenrij met $90 \%$ driftreducerende spuitdop (TVI8001 op 7 bar) en automatische hoekverdraaiing van de spuitmonden.

De drift van de HSS-CF werd vergeleken met die van de Munckhof dwarsstroomspuit voorzien van Albuz ATR Lila doppen (referentietechniek; Huijsmans et al., 1997). In paragraaf 2.1.1 staan karakteristieken beschreven van de in de proeven gebruikte Munckhof standaard boomgaardspuit en in paragraaf 2.1.2 staat een beschrijving van de HSS-CF dwarsstroomspuit. In paragraaf 2.1.3 staat een samenvattend overzicht van de gebruikte spuittechnieken.

\subsubsection{Karakteristieken Munckhof standaard boomgaardspuit}

De in Nederland voor driftonderzoek gebruikte standaard boomgaardspuit is de Munckhof dwarsstroomspuit (Huijsmans et al., 1997). De Munckhof dwarsstroomspuit is een axiaalspuit voorzien van een dwarsstroomkap op de ventilator (Figuur 2.1).

In Tabel 2.1 staan de posities van de tien dophouders van de Munckhof dwarsstroomspuit boven grondoppervlak weergegeven.

Tabel 2.1 Dophoogte vanaf de grond [cm] van de dophouders op de Munckhof dwarsstroomspuit.

\begin{tabular}{llllllllllll} 
Dopnr & 1 & 2 & 3 & 4 & 5 & 6 & 7 & 8 & 9 \\
links & 50 & 68 & 84 & 99 & 120 & 153 & 180 & 215 & 250 & 285 \\
\hline rechts & 48 & 66 & 81 & 99 & 121 & 153 & 181 & 216 & 251 & 286 \\
\hline
\end{tabular}

Er werd gespoten met $2 \times 8$ geopende spuitdoppen, waarbij de onderste $(50 \mathrm{~cm})$ en de bovenste dop (op $285 \mathrm{~cm}$ ) waren gesloten. De bovenste spuitende dop zat op 2,50 m hoogte in overeenstemming met de toppen van de fruitbomen. De spuit werd aangedreven door een New Holland T4050N fruitteelt trekker, met een rijsnelheid van $6,4 \mathrm{~km} / \mathrm{h}$ en een aftakas toerental van $540 \mathrm{rpm}$.

Er werd gemeten bij de vollucht stand van de ventilator, hierbij was de gemiddelde luchtsnelheid links en rechts over de gehele luchtspleet $21 \mathrm{~m} / \mathrm{s}$. Bij de bespuitingen werd de drift vastgelegd bij gebruik van Albuz ATR Lila werveldoppen en een druk van 7 bar (referentie) en een spuitvolume van 209 l/ha. 


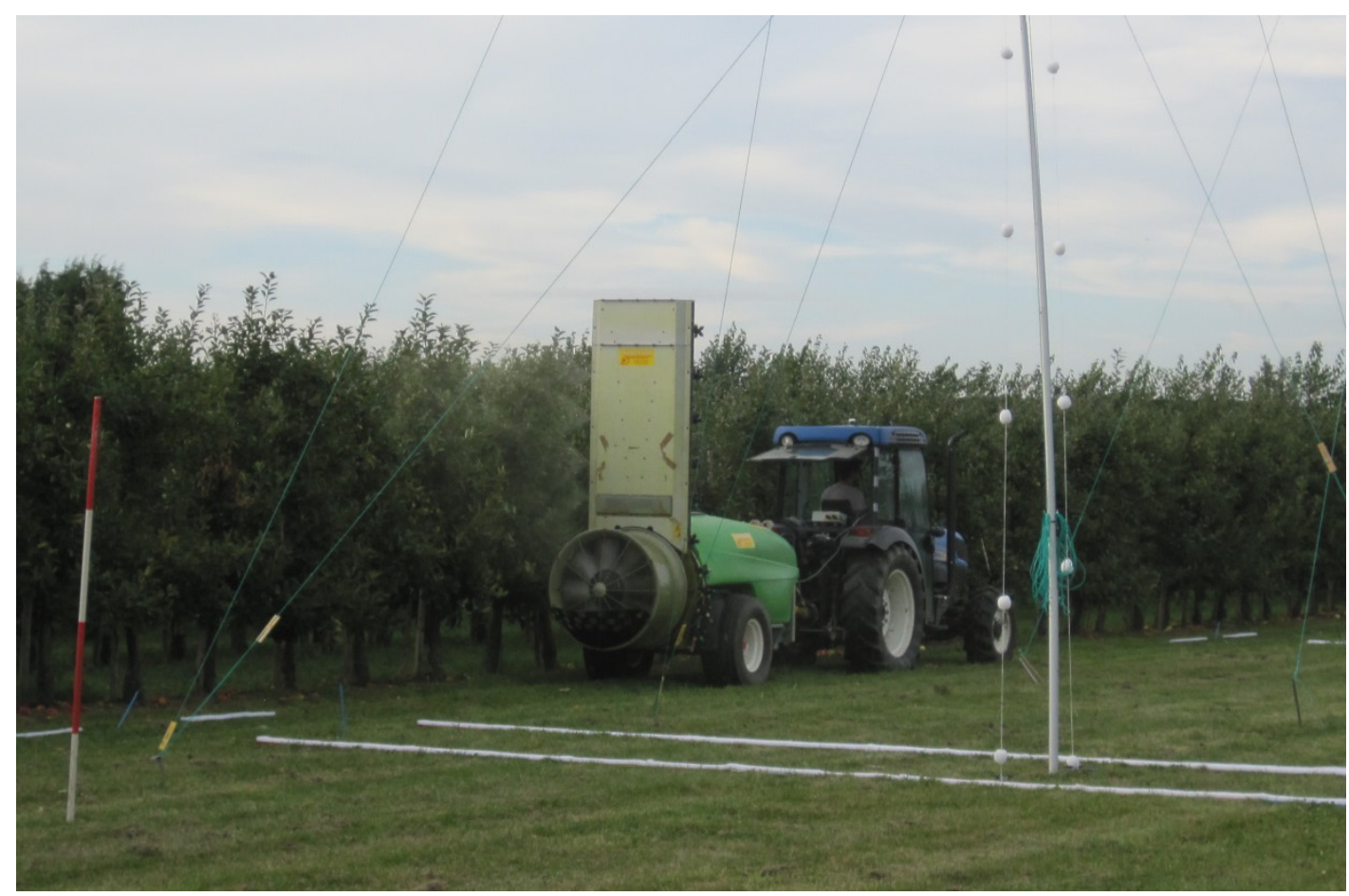

Figuur 2.1 Standaard boomgaardspuit (Munckhof dwarsstroom) tijdens driftmetingen.

\subsubsection{Karakteristieken H.S.S. CF dwarsstroomspuit}

De H.S.S. CF dwarsstroomspuit is een radiaalspuit met centrifugaalventilator met slangen naar blaasmonden op een dwarsstroomtoren (Figuur 2.3). Door de constructie van de spuit zuigt de ventilator geen spuitvloeistof aan en blaast daardoor aan de zijde waar niet gespoten wordt geen spuitvloeistof uit. Het is daardoor niet nodig de blaasmonden af te sluiten aan de kant waar niet wordt gespoten. Aan weerszijden op de dwarsstroomtoren zitten acht blaasmonden met per blaasmond een wisseldophouder voor twee spuitdoppen (Figuur 2.3, Tabel 2.2). De blaasmond - spuitdop combinatie kan per spuitzijde in richting versteld worden. Verdraaiing van de blaasmonden is met actuators die op het frame van de spuit bevestigt zijn. De richting van de blaasmonden kan handmatig met de spuitcomputer ingesteld worden of automatisch afhankelijk van de windrichting en snelheid. Voor het meten van de windrichting en windsnelheid is op de spuit een windmeet bol bevestigd (Figuur 2.3, 2.5). Door middel van een vaste instelling voor de linkse en rechtse blaasmonden in de Automatic Wind Control (AWC) spuitcomputer past de spuit dit automatisch aan aan de hand van de rijrichting en de heersende windrichting. Tijdens de driftmetingen was de instelling zo dat aan de windzijde de blaasmond tegen de wind in dwars op de rijrichting stond en aan de benedenwindse zijde van de spuit de blaasmond 20 graden naar achteren gedraaid stond (Figuur 2.2 en 2.4).
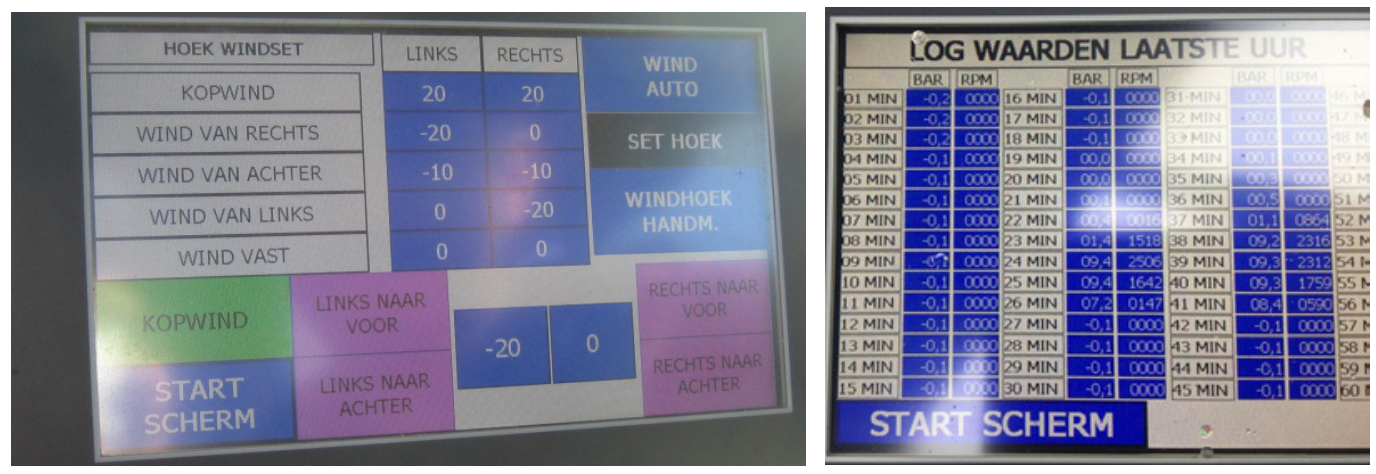

Figuur 2.2 Instelling blaasmonden luchtondersteuning met H.S.S. Automatic Wind Control (AWC); wind van links of wind van rechts dan is aan de windzijde de hoek 0 en dwars op de rijrichting en de andere zijde is dan -20 graden en schuin naar achteren gedraaid; vastleggen spuitdruk(bar) en toerental (rpm) ventilator in H.S.S. Drift Control box (rechts). 
Deze instelling klapte vanzelf om als de spuit aan het eind van het spuitpad op de kopakker draaide en het volgende spuitpad in ging en de wind van de andere kant van de spuit kwam.

De luchtondersteuning kan hoog en laag ingesteld worden door middel van een handel (Figuur 2.5). Tijdens de driftmetingen stond de luchtondersteuning in de lage stand. Het toerental van de ventilator kan met de H.S.S. AWC ingesteld en tijdens de bespuiting vastgelegd (Figuur 2.2) worden en was tijdens de driftmetingen $1800 \mathrm{rpm}$.
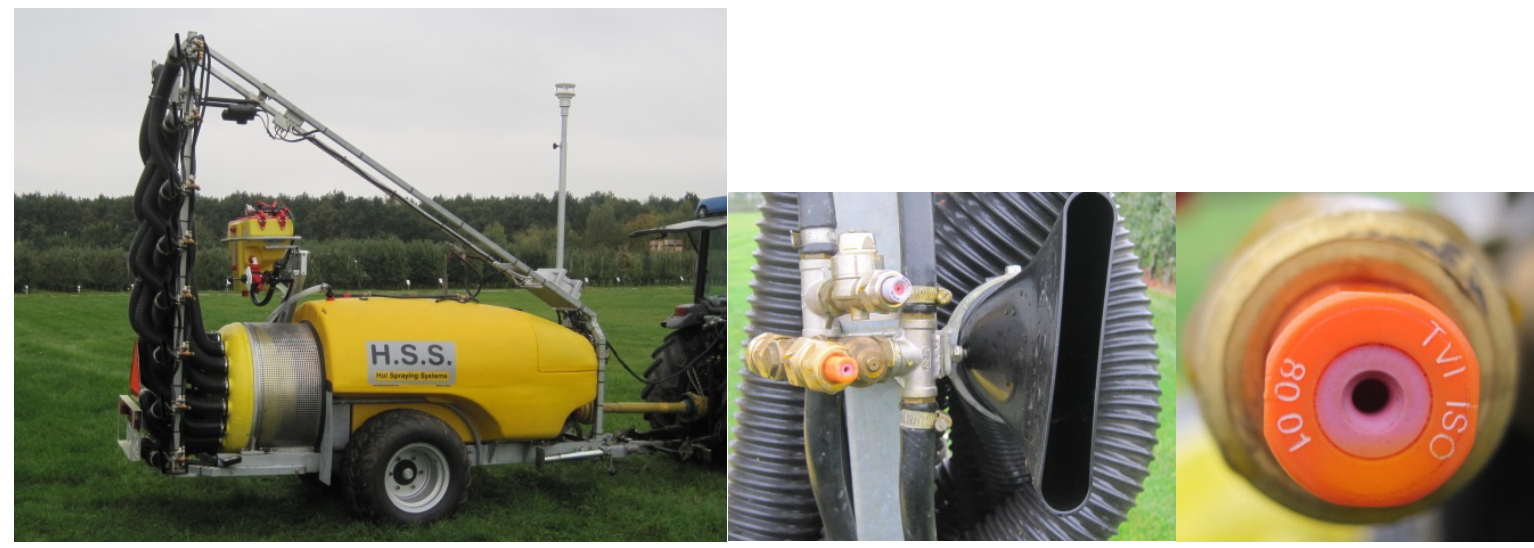

Figuur 2.3 H.S.S. CF dwarsstroomspuit met actuatoren voor hoekverstelling blaasmonden en windmeetbol (links), blaasmond met dophouder combinatie (midden) en venturi werveldoppen (Albuz TVI8001 oranje; rechts).

De druk van de spuitdoppen wordt met de H.S.S. Controle box met de optie H.S.S. Drift Control en een digitale drukmeter ingesteld en vastgelegd (Figuur 2.2). De spuit is uitgerust met dubbele dophouders zodat snel van spuitdop gewisseld kan worden en/of met een dubbel leiding systeem voor aparte aansturing van twee spuitdoppen (Figuur 2.3).
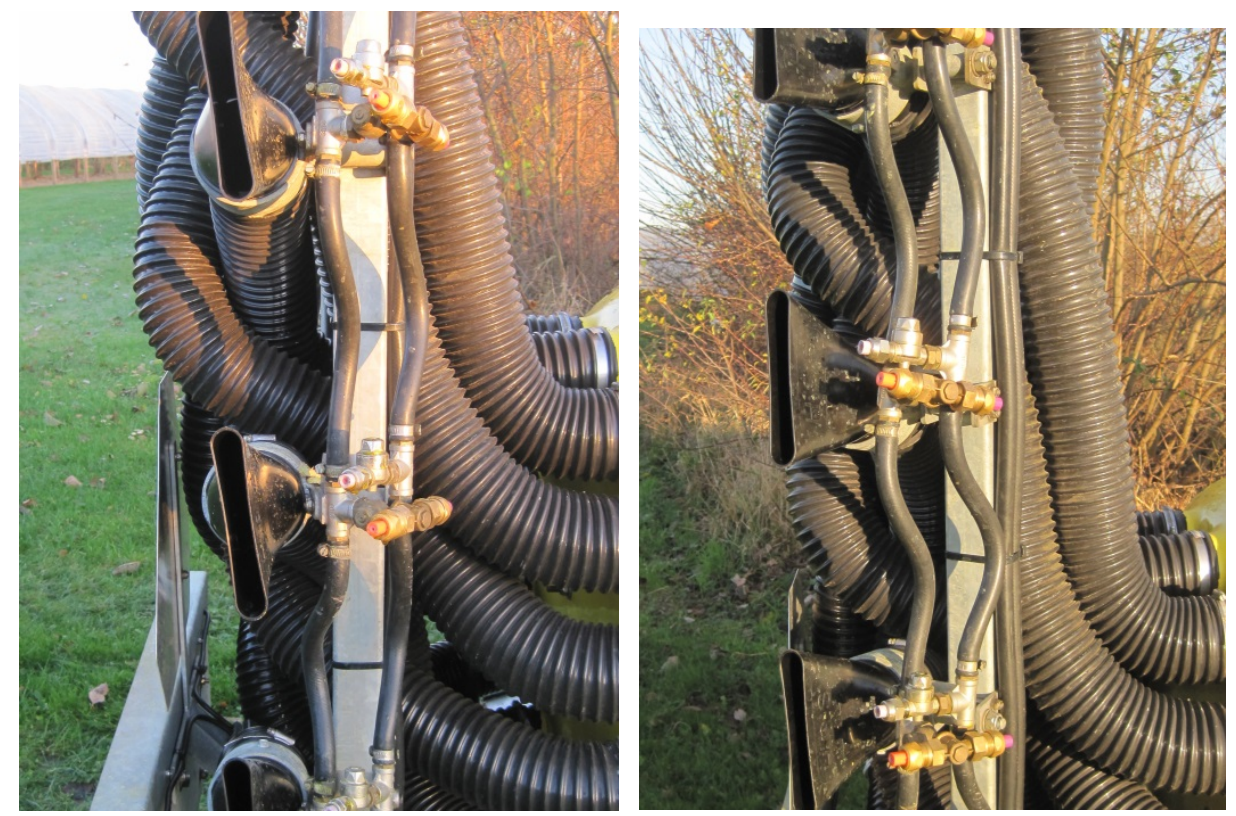

Figuur 2.4 Blaasmonden luchtondersteuning dwars op de rijrichting (links) en schuin naar achteren gedraaid (rechts).

De spuit was aan beide kanten met 8 spuitdoppen uitgerust. Er werd gespoten met $2 \times 7$ geopende spuitdoppen, waarbij de bovenste spuitdoppen (op $283 \mathrm{~cm}$ ) waren gesloten.

In Tabel 2.2 staan de posities van de dophouders op de HSS-CF boven grondoppervlak weergegeven. 
Tabel 2.2 Dophoogte vanaf de grond [cm] van de dophouders op de HSS-CF.

\begin{tabular}{lccccccccc} 
Dopnr & 1 & 2 & 3 & 4 & 5 & 6 & 7 & 8 \\
links+rechts & 45 & 76 & 107 & 140 & 171 & 203 & 243 & 283 \\
\hline
\end{tabular}
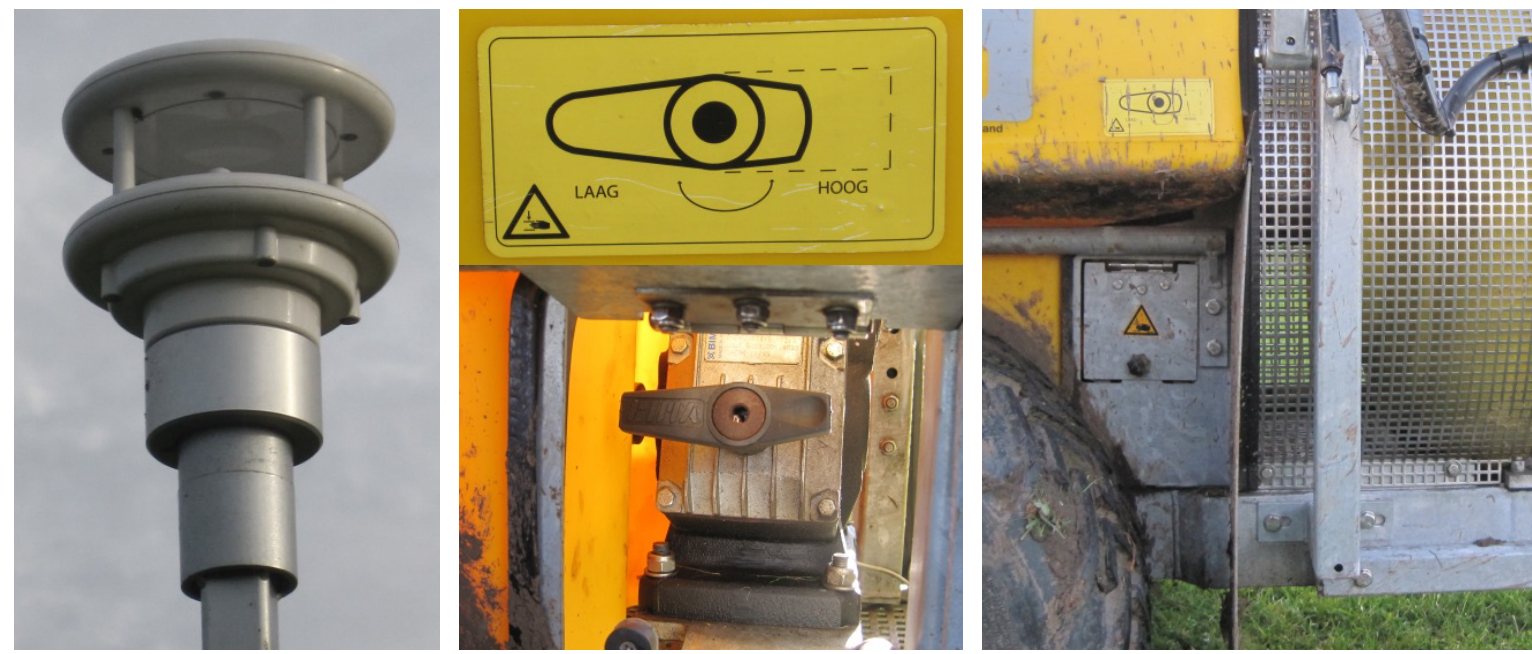

Figuur 2.5 Windsnelheid en windrichting sensor (links) op de H.S.S. CF voor het bepalen van de spuitmond verdraaiing links en rechts afhankelijk van de wind met H.S.S. AWC bij de lage instelling van de luchtondersteuning (midden, rechts; stand handel achter klep onder tank voor ventilator).

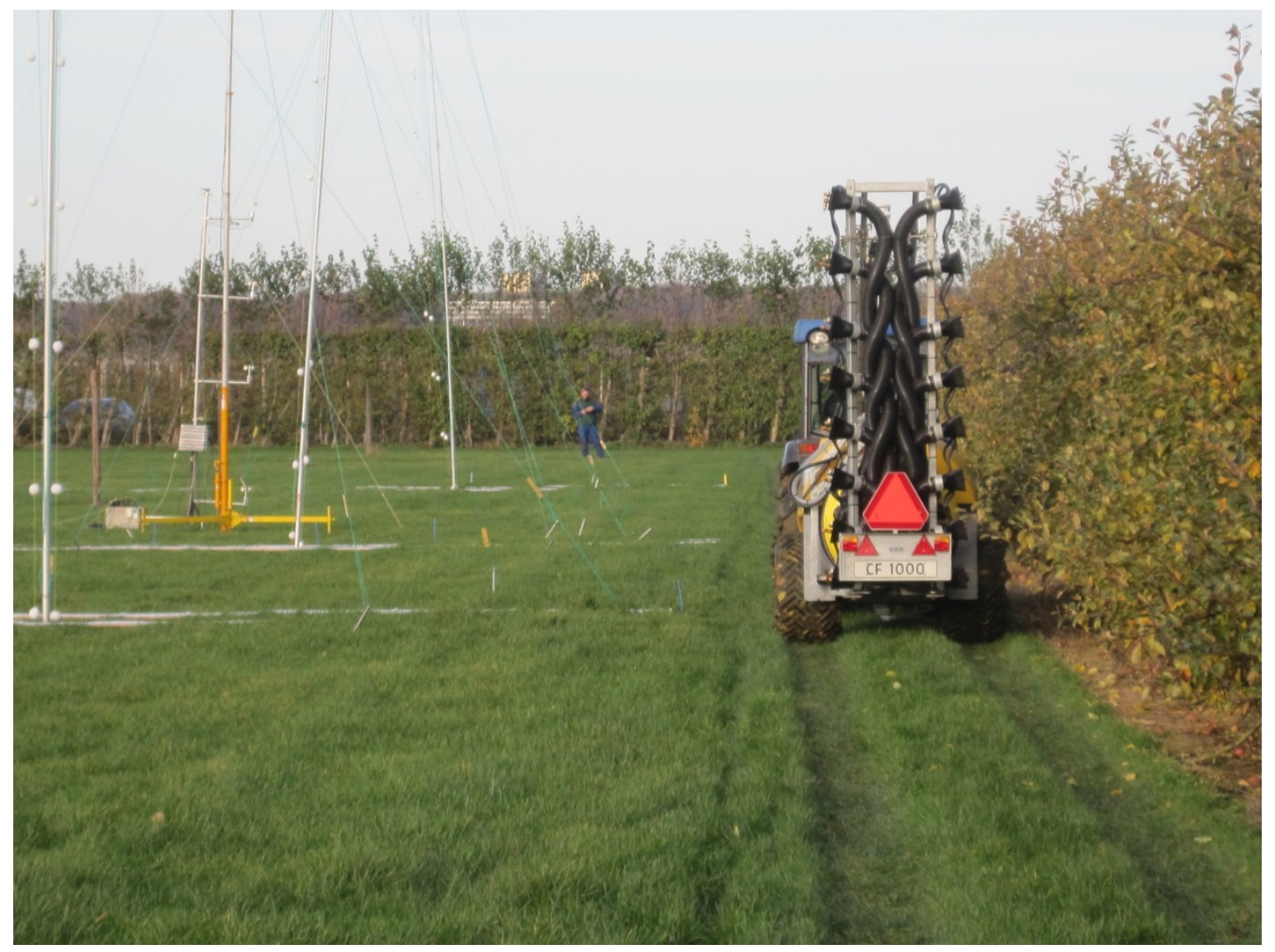

Figuur 2.6 H.S.S. CF dwarsstroomspuit tijdens driftmetingen.

Tijdens de driftmetingen (Figuur 2.6) werd er gespoten met $2 \times 7$ geopende spuitdoppen (bovenste twee doppen gesloten). De bovenste spuitende dop zat op 2,43 $\mathrm{m}$ hoogte in overeenstemming met de toppen van de fruitbomen. De spuit werd aangedreven door een New Holland T4050N fruitteelt trekker. De rijsnelheid bij een aftakastoerental van $400 \mathrm{rpm}$ was 6,5 km/h. De drift werd gemeten bij 
de lage luchtinstelling van de ventilator (Figuur 2.5) waarbij gemiddeld over de verschillende blaasmonden de uittrede snelheid van de lucht $10 \mathrm{~m} / \mathrm{s}$ was op 1,5 m van de spuit bij $1800 \mathrm{rpm}$ van de ventilator. Bij de bespuitingen werd de drift vastgelegd bij gebruik van TVI 8001 venturi werveldoppen (Figuur 2.3) bij een druk van 7 bar. Het spuitvolume was 262 I/ha.

\subsubsection{Samenvatting gebruikte spuittechnieken}

In Tabel 2.3 staat een samenvatting van de tijdens de driftmetingen gebruikte spuittechnieken.

Tabel 2.3 Samenvatting gebruikte spuittechnieken in de driftmetingen.

\begin{tabular}{|c|c|c|}
\hline Spuit & Munckhof dwarsstroom & Hol HSS-CF \\
\hline aftakas & 540 & 400 \\
\hline Spuitdoppen & ATR Lila & TVI 8001 \\
\hline doptype & Werveldop & Venturi werveldop \\
\hline n-doppen & $2 \times 8$ & $2 \times 7$ \\
\hline dop afgifte $[\mathrm{I} / \mathrm{min}]$ & 0,42 & 0,61 \\
\hline rijsnelheid $[\mathrm{km} / \mathrm{h}]$ & 6,4 & 6,5 \\
\hline spuitvolume [l/ha] & 209 & 262 \\
\hline
\end{tabular}

\subsection{Beschrijving metingen en verwerking resultaten}

\subsubsection{Metingen}

De experimenten werden op 28 september, 28 oktober, 24 november en 25 november 2016 uitgevoerd op de proeftuin van WPR-fruit te Randwijk, op perceel Oost in overeenstemming met de driftmeetprotocollen CIW (2003) en ISO22866. Dit perceel is aangeplant met het appelras Elstar. De fruitbomen staan in een plantverband van 1,10 m afstand in de rij en $3 \mathrm{~m}$ tussen de rijen (rijafstand). De bomen waren 2,25 $\mathrm{m}$ hoog en in het volblad stadium (BBCH 90). Het perceel bestond uit een blok van 110 meter lengte en 14 rijen $(52 \mathrm{~m}$ ) breed (Figuur 2.5). Daaromheen lag een strook gras van ongeveer $30 \mathrm{~m}$ breed. Op deze strook gras werden twee driftmeetstroken uitgelegd (Figuur 2.7). Tijdens de driftmetingen werden de laatste acht bomenrijen ( $24 \mathrm{~m}$ ) aan de benedenwindse zijde volledig bespoten. Met één en dezelfde instelling werd steeds het blok van acht boomrijen bespoten.

Bij elke driftmeetstrook werden twee meetraaien (duplo bepalingen) uitgelegd met 1 meter tussenruimte tussen de meetraaien. In het meetgedeelte naast het perceel werden 2 herhalingen van de driftmeetstroken achter elkaar gelegd, op een onderlinge afstand van $30 \mathrm{~m}$.

Op de volgende posities werden collectoren (Technofil TF $290 ; 10 \times 100 \mathrm{~cm}, 10 \times 50 \mathrm{~cm}$ ) gelegd om de driftdepositie naar de grond te meten:

- Op 1,5 meter, evenwijdig aan de buitenste bomenrij, een collector van 1 meter lengte.

- Op 3 - 15 meter aaneengesloten collectoren van 0,5 meter (haaks op de bomenrij).

- Op 20 en 25 meter een collector van 1 meter (haaks op de bomenrij).

De afstand werd gemeten vanaf het midden (hart) van de buitenste bomenrij.

De emissie naar de lucht werd op 7,5 m vanaf de laatste bomenrij met behulp van een mast van $10 \mathrm{~m}$ hoogte gemeten, met op elke meter hoogte een driftbolcollector (Siebauer Abtrifftkollektoren). 


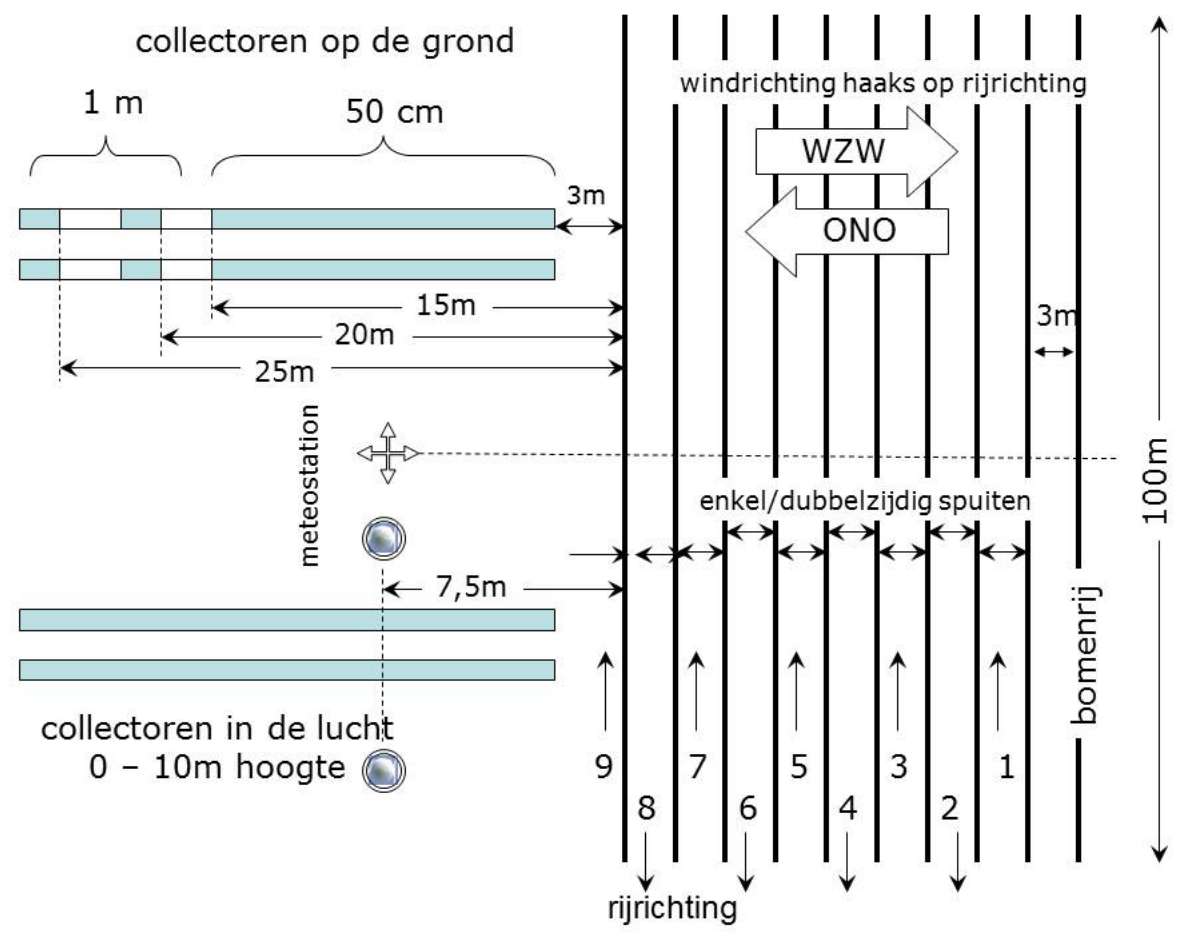

Figuur 2.7 Schematische weergave proefveld en meetopstelling.

\subsubsection{Analyses}

De bespuitingen werden uitgevoerd met water waaraan Brilliant Sulfo Flavine (BSF, Chroma 1F 561, CI 56205, 2-4 g/l) en een niet-ionische uitvloeier (Agral Gold, 0,075 ml/l) was toegevoegd. $\mathrm{Na}$ de bespuiting werden de collectoren verzameld en gecodeerd voor verdere analyse op de hoeveelheid BSF. Elke meetdag werden ook monsters genomen uit de tank om de BSF-concentratie van de verspoten spuitvloeistof te meten. In het laboratorium werden de collectoren met gedemineraliseerd water gespoeld, zodanig dat de BSF in oplossing kwam. Van deze oplossing werd de concentratie aan BSF gemeten met behulp van een fluorimeter (Perkin Elmer LS 55; $\lambda_{\mathrm{ex}}=450 \mathrm{~nm}$; $\lambda_{\mathrm{em}}=500 \mathrm{~nm}$ ). Voor het bepalen van de achtergrondfluorescentie werden blanco collectoren geanalyseerd. De concentratie BSF in de tankmonsters werd ook fluorimetrisch bepaald.

\subsubsection{Berekeningen en statistiek}

De concentratie werd omgerekend naar volume spuitvloeistof per oppervlakte-eenheid. Het percentage drift is berekend door de driftdepositie per oppervlakte-eenheid uit te drukken in procenten van de door de spuitdoppen in het perceel verspoten hoeveelheid vloeistof per oppervlakteeenheid.

De gemeten fluorescentiewaarde werd omgerekend naar de driftdepositie $\left(\mu \mathrm{l} / \mathrm{cm}^{2}\right)$ volgens:

$$
D_{\text {monster }}=\frac{\left(F_{\text {monster }}-F_{\text {demi }}-F_{\text {blanco }}\right) \times f_{i j k} \times V_{\text {spoel }}}{C_{t m} \times A_{\text {monster }}}
$$

$\mathrm{D}=$ depositie in $\mu \mathrm{l} / \mathrm{cm}^{2}$;

$\mathrm{F}=$ fluorescentiewaarde $; F_{\text {monster }}=$ fluorescentiewaarde van het monster $; F_{\text {demi }}=$ fluorescentiewaarde van demiwater; $F_{\text {blanco }}=$ bijdrage van de achtergrond door collector;

$\mathrm{f}_{\mathrm{ijk}}=\mathrm{ijkfactor} ; \mathrm{V}_{\text {spoel }}=$ extractievolume in liter;

$\mathrm{C}_{\mathrm{tm}}=$ spuitvloeistofconcentratie in tank in $\mathrm{g}^{-1}{ }^{-1} ; \mathrm{A}_{\text {monster }}=$ monsteroppervlak in $\mathrm{cm}^{2}$. 
Voor de statistische verwerking wordt indien $\left(F_{\text {monster }}-F_{\text {demi }}-F_{\text {blanco }}\right)$ kleiner of gelijk aan 0 is, hier een kleine waarde ingevuld $(0,001)$.

Vervolgens werd per monster de driftdepositie uitgedrukt als percentage van het uitgebracht spuitvolume volgens:

$$
P=\frac{D_{m}}{Q / 100} \times 100 \%
$$

$P=$ percentage drift van het uitgebrachte spuitvolume; $D_{m}=$ driftdepositie in $\mu \mathrm{l} / \mathrm{cm}^{2}$;

$\mathrm{Q}=$ spuitvolume in $\mathrm{l} / \mathrm{ha}$

Voor de vergelijking van de driftdepositie van de verschillende spuittechnieken zijn de driftwaarden (\% van spuitvolume) uitgerekend voor verschillende evaluatiestroken overeenkomend met de positie van de sloot (insteek-insteek afstand $4 \mathrm{~m}$ ) en het wateroppervlak daarbinnen $(1 \mathrm{~m})$. De teeltvrije zone wordt in het Activiteitenbesluit Milieubeheer (I\&M, 2012) gedefinieerd als de afstand tussen de insteek van de sloot en de buitenste gewasrij (voor fruitteelt $3 \mathrm{~m}$ in Figuur 2.8). De volgende evaluatiestroken worden onderscheiden:

- slootoppervlak: 3-7, 41/2-81/2, 6-10 en 9-13 m, bij respectievelijk 3, 41/2, 6 en 9 m teeltvrije zone.

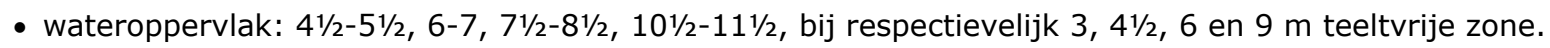

- naar de lucht: gemiddeld over $10 \mathrm{~m}$ hoogte op 7,5 m vanaf de laatste bomenrij.

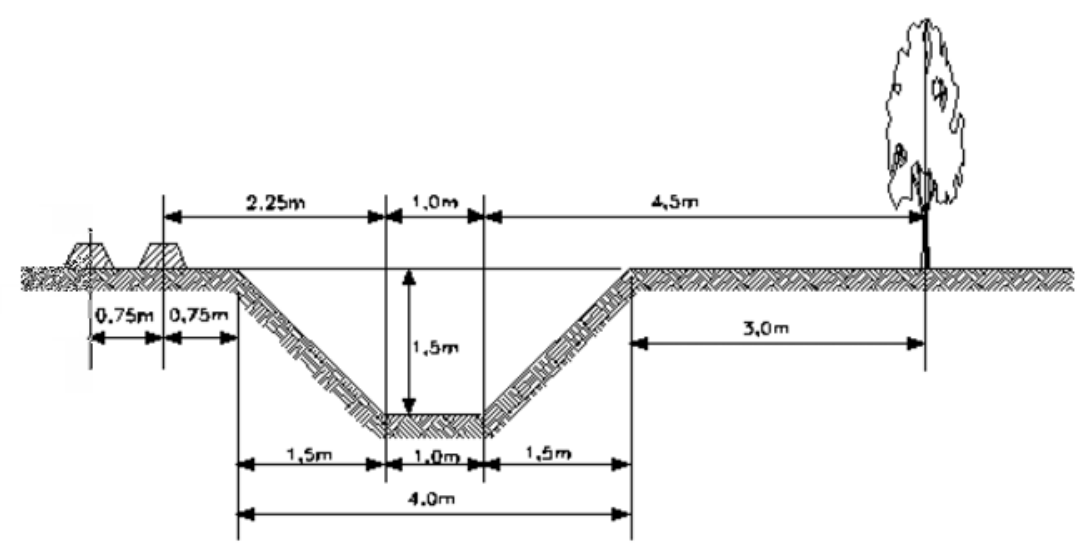

Figuur 2.8 Schematische weergave van de plaats van de sloot, het talud en het wateroppervlak ten opzichte van de laatste gewasrij in aardappelen (links) en de buitenste bomenrij in de fruitteelt (rechts) (Huijsmans et al., 1997).

De gekozen zones van $3 \mathrm{~m}, 41 \frac{2}{2} \mathrm{~m}, 6 \mathrm{~m}$ en $9 \mathrm{~m}$ komen overeen met de in artikel 3.80 van het Activiteitenbesluit Milieubeheer (I\&M, 2012) genoemde zones. Daarbij is $9 \mathrm{~m}$ de teeltvrije zone waarbij een bespuiting nog met een standaard spuittechniek uitgevoerd mag worden. De zones $3 \mathrm{~m}$ en $41 / 2 \mathrm{~m}$ gelden als teeltvrije zone als de bespuiting uitgevoerd wordt met een driftbeperkende techniek of maatregel (zoals genoemd in het Activiteitenbesluit). Voor de kopakker geldt een teeltvrije zone van $6 \mathrm{~m}$ in plaats van $9 \mathrm{~m}$ mits bij de bespuiting van de buitenste bomenrij geen gebruik gemaakt wordt van naar het oppervlaktewater gerichte apparatuur. 
De verschillen in driftdepositiewaarden op de evaluatiestroken tussen de verschillende spuittechnieken werden getoetst bij een onbetrouwbaarheidsdrempel van $5 \%$. Statistische analyse vond plaats met behulp van het statistische programma Genstat (Genstat Release 9.2, Payne et al., 2006). Bij de statistische analyse werd gebruik gemaakt van de Genstat procedure IRREML (Keen en Engel, 1998). In Bijlage 1 staat het gebruikte IRREML script.

Voor de indeling van de HSS-CF met de verschillende instellingen in driftreductieklassen (ISO22369-1) werd de driftreductie op de gemeten afstanden en de evaluatiestroken berekend ten opzichte van de driftdepositie van de referentie bespuiting met de Munckhof dwarsstroomspuit uitgerust met Albuz ATR Lila doppen volgens:

$$
\% \text { reductie }=\frac{\left(P_{\text {driftref }}-P_{\text {techniek }}\right)}{P_{\text {driftref }}} \times 100 \%
$$

$\mathrm{P}_{\text {driftref }}=$ Percentage drift referentietechniek en dop (Munckhof dwarsstroom met Albuz ATR Lila spuitdoppen)

$\mathrm{P}_{\text {techniek }}=$ Percentage drift H.S.S. CF bij de verschillende instellingen

\subsection{Weersomstandigheden}

Tijdens de bespuitingen werden de weersomstandigheden vastgelegd door meting van de temperatuur (Pt100 op 0,5 m en $4 \mathrm{~m}$ hoogte), de luchtvochtigheid (\% RV met een Rhotronic op 1,5 m hoogte), de windrichting $\left(0^{\circ}=\right.$ haaks t.o.v. de bomenrijen) op $10 \mathrm{~m}$ hoogte en de windsnelheid (cupanemometers op $0,5,2,3,4$ en $10 \mathrm{~m}$ hoogte) met een tijdsinterval van 5 seconden.

De meteomast stond op 7,5 m afstand vanaf de buitenste bomenrij (zie Figuur 2.5). Bij elke passage van de spuit ter hoogte van het midden van de twee meetopstellingen werd de tijd van de datalogger genoteerd. Later werd uit de verzamelde data vanuit dit passagetijdstip over 15 seconden vóór en 15 seconden ná passeertijdstip de meetwaarde gemiddeld. In Bijlage 2 staan de resultaten van de metingen van de weersomstandigheden vermeld.

De H.S.S. CF met lage luchtinstelling en 2-zijdig spuiten van de buitenste bomenrij met TVI8001 venturi werveldoppen (HSS-CF -A) zijn niet steeds op dezelfde dag gemeten als de H.S.S. CF met lage luchtinstelling en 1-zijdig bespuiten van de buitenste bomenrij met TVI8001 venturi werveldoppen (HSS-CF -B) en de H.S.S. CF met lage luchtinstelling, 1-zijdig bespuiten van de buitenste bomenrij met TVI8001 venturi werveldoppen en automatische hoekverdraaiing van de spuitmonden (HSS-CF -C). De resultaten zijn steeds vergeleken met de standaardbespuiting gemeten op dezelfde dag. Resultaten HSS-CF -A zijn vergeleken met herhaling 1-11 van de standaard en HSS-CF -B en HSS-CF -C zijn vergeleken met herhaling 7-16 van de standaard.

De metingen werden uitgevoerd in 2016 op:

- 28 september (standaard:\#1-4; HSS-CF -A: \#1-4)

- 28 oktober (standaard: \#5-8; HSS-CF -A: \#5-8; HSS-CF -B:\#1-2; HSS-CF -C: \#1-2)

- 24 november (standaard: \#9-11; HSS-CF -A:(\#9-10; HSS-CF -B: \#3-5; HSS-CF -C: \#3-5)

- 25 november (standaard: \#12-16; HSS-CF -B; \#6-10; HSS-CF -C: \#6-10)

Bij HSS-CF - C waren twee herhalingen waarbij de gemiddelde windsnelheid over 9 passages onder de $5 \mathrm{~m} / \mathrm{s}$ was. Bij de bespuitingen van de buitenste 2 rijen werden bij deze metingen windsnelheden gemeten van respectievelijk 5,8 m/s bij \#6 en 6,1 m/s bij \#8. Omdat de bespuiting van de buitenste twee boomrijen de meeste bijdrage op de drift geven (50\%-65\%; Wenneker et al., 2007) zijn deze metingen niet meegenomen bij de beschrijving van de resultaten. 
Bij de HSS-CF - A en HSS-CF -B zijn respectievelijk \#4 en \#7 niet meegenomen bij de beschrijving van de resultaten. De reden waarom wordt aangegeven in hoofdstuk 3.

Tijdens een aantal metingen kon er door een defect aan de sensor geen \%RV gemeten worden. Het is dan niet zinvol om een gemiddelde te presenteren.

De gemiddelde weersomstandigheden van de metingen staan in Tabel 2.4.

Tabel 2.4 Gemiddelde weersomstandigheden voor de verschillende technieken tijdens de driftmetingen.

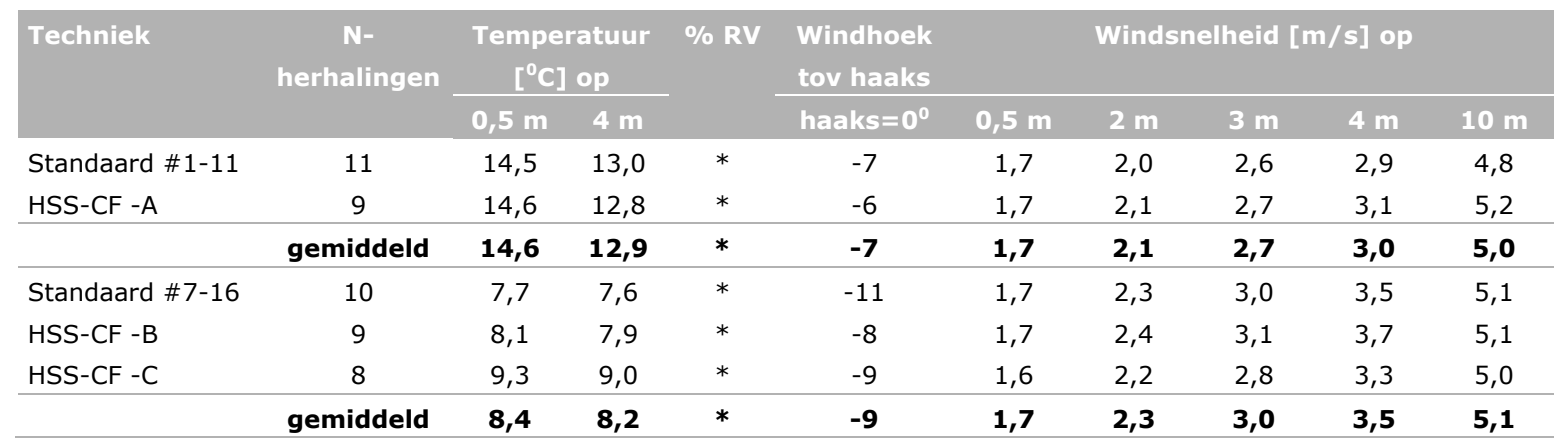

*=geen gemiddelde door defect sensor.

Tijdens de driftmetingen met HSS-CF -A was de gemiddelde temperatuur op $4 \mathrm{~m}$ hoogte $12,9^{\circ} \mathrm{C}$, de gemiddelde windhoek $-7^{\circ}$ ten opzichte van de bomenrij en de gemiddelde windsnelheid $2,1 \mathrm{~m} / \mathrm{s}$ op $2 \mathrm{~m}$ hoogte en 3,0 m/s op $4 \mathrm{~m}$ hoogte (ongeveer $1 \mathrm{~m}$ boven de bomen). Bij metingen met HSS-CF -B en HSS-CF -C was de gemiddelde temperatuur $8,2{ }^{\circ} \mathrm{C}$, de windhoek $-9^{\circ}$ en de gemiddelde windsnelheid $2,3 \mathrm{~m} / \mathrm{s}$ op $2 \mathrm{~m}$ hoogte en $3,5 \mathrm{~m} / \mathrm{s}$ op $4 \mathrm{~m}$ hoogte. 


\section{Resultaten}

De resultaten van de metingen van de drift naar de grond naast het perceel zijn weergegeven in Bijlage 3 en de resultaten van de drift naar de lucht zijn weergegeven in Bijlage 4. De H.S.S. CF met lage luchtinstelling en 2-zijdig spuiten van de buitenste bomenrij met TVI8001 venturi werveldoppen (HSS-CF -A) zijn niet steeds op dezelfde dag gemeten als de H.S.S. CF met lage luchtinstelling en 1-zijdig bespuiten van de buitenste bomenrij met TVI8001 venturi werveldoppen (HSS-CF -B) en de HSS-CF met lage luchtinstelling, 1-zijdig bespuiten van de buitenste bomenrij met TVI8001 venturi werveldoppen en automatische hoekverdraaiing van de spuitmonden (HSS-CF $-\mathrm{C}$ ). De resultaten zijn steeds vergeleken met de standaardbespuiting gemeten op dezelfde dag. Resultaten HSS-CF -A zijn vergeleken met herhaling 1-11 van de standaard en HSS-CF -B en HSS-CF -C zijn vergeleken met herhaling 7-16. In de verdere presentatie van de resultaten wordt HSS-CF -A apart weergegeven van de HSS-CF -B en HSS-CF -C.

In Bijlage 3 is te zien dat bij herhaling 4 van de HSS-CF -A er een groot verschil is tussen de twee rijen met collectoren terwijl er maar $2 \mathrm{~m}$ afstand tussen de rijen is. Op de strook $4 \frac{1}{2}-51 \frac{1}{2}$ wordt bij rij $1 \sim 2,5$ keer zoveel drift gevonden als bij rij 2. Ook bij herhaling 7 van de HSS-CF -B van de buitenste bomenrij wordt een groot verschil gevonden tussen de rijen. Op 41/2-51/2 m is de drift bij rij 13 keer zo hoog als bij rij 2. Op grond van ervaring bij andere driftmetingen lijken deze metingen onbetrouwbaar en zijn deze metingen niet meegenomen in de beschrijving van de resultaten.

\subsection{Drift naar de grond naast het perceel}

\subsubsection{HSS-CF -A}

De gemiddelde drift per spuittechniek tijdens bespuitingen in de volblad situatie (BBCH 90) staat weergegeven in Figuur 3.1 en in Tabel 3.1.

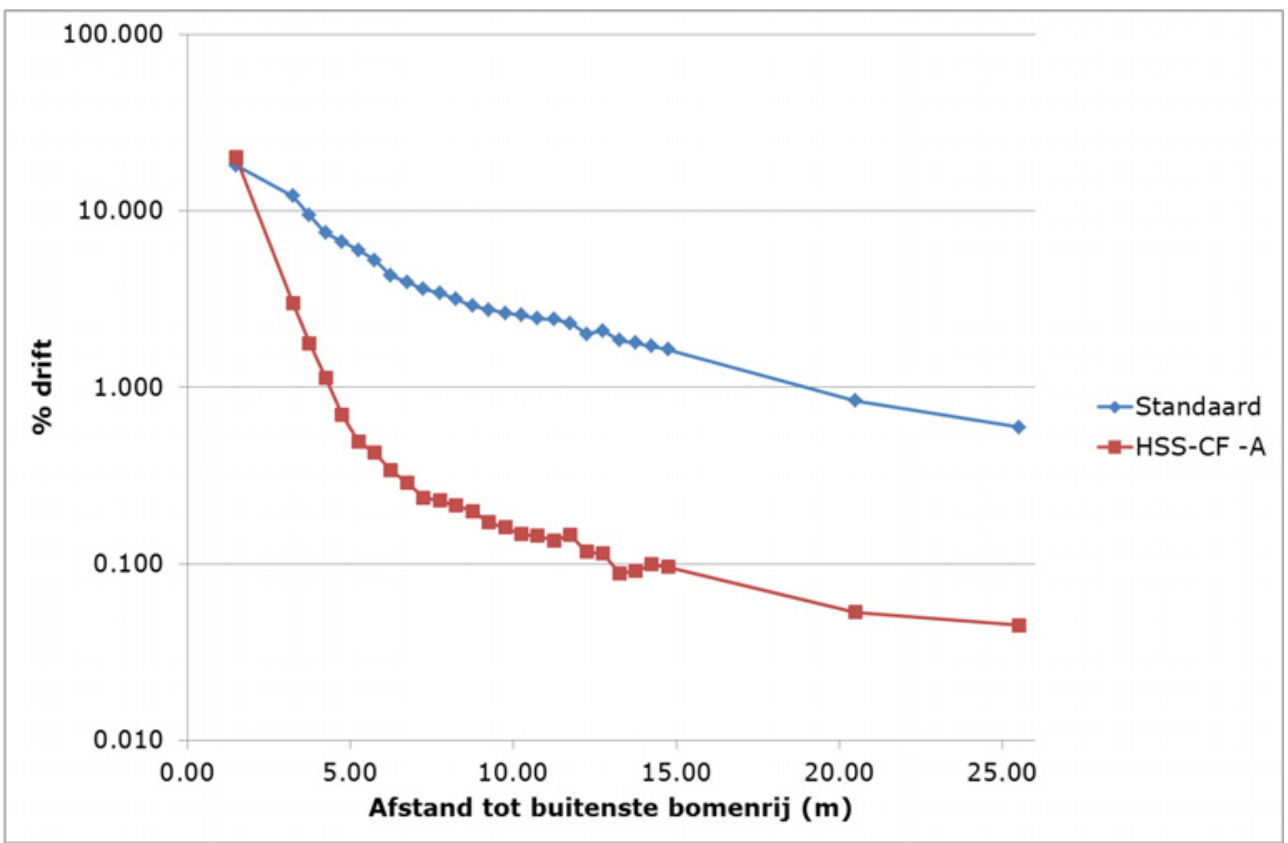

Figuur 3.1 Gemiddelde drift (\% van verspoten hoeveelheid spuitvloeistof per oppervlakte-eenheid) op verschillende afstanden vanaf het hart van de buitenste bomenrij bij bespuitingen van appelbomen in de volblad situatie (BBCH 90)met een standaard dwarsstroomspuit (Munckhof met ATR lila werveldoppen) en een H.S.S. CF met lage luchtinstelling en 2-zijdig spuiten van de buitenste bomenrij met TVI8001 venturi werveldoppen (HSS-CF - A). 
In Figuur 3.1 en Tabel 3.1 is te zien dat de standaard spuit (Munckhof dwarsstroom met ATR Lila werveldoppen) meer drift geeft dan de HSS-CF -A. In Tabel 3.3 is dat voor de verschillende evaluatiestroken weergegeven.

Tabel 3.3 Gemiddelde drift (\% van verspoten hoeveelheid spuitvloeistof per oppervlakte-eenheid) op de evaluatiestroken overeenkomend met teeltvrije zones van $3 m, 41 / 2 m, 6 m$ en $9 m$ bij bespuitingen van appelbomen in het volblad stadium (BBCH 90) met een standaard dwarsstroomspuit (Munckhof met ATR lila werveldoppen) en een H.S.S. CF met lage luchtinstelling en 2-zijdig spuiten van de buitenste bomenrij met TVI8001 venturi werveldoppen (HSS-CF -A).

\begin{tabular}{|c|c|c|c|c|c|c|c|c|c|c|c|c|c|c|c|c|}
\hline \multirow{3}{*}{$\begin{array}{l}\text { Techniek } \\
\text { Standaard }\end{array}$} & \multicolumn{16}{|c|}{ Afstand tot buitenste bomenrij ( $\mathrm{m}$ ) } \\
\hline & \multicolumn{4}{|c|}{$3 \mathrm{~m}$ teeltvrij } & \multicolumn{4}{|c|}{$41 / 2 \mathrm{~m}$ teeltvrij } & \multicolumn{4}{|c|}{$6 \mathrm{~m}$ teeltvrij } & \multicolumn{4}{|c|}{$9 \mathrm{~m}$ teeltvrij } \\
\hline & \multicolumn{2}{|c|}{ 3-7 } & \multicolumn{2}{|c|}{$41 / 2-51 / 2$} & \multicolumn{2}{|c|}{$41 / 2-81 / 2$} & \multicolumn{2}{|c|}{$6-7$} & \multicolumn{2}{|c|}{$6-10$} & \multicolumn{2}{|c|}{$71 / 2-81 / 2$} & \multicolumn{2}{|c|}{$9-13$} & \multicolumn{2}{|c|}{$101 / 2-11 \frac{1}{2}$} \\
\hline HSS-CF - A & 1,02 & $b$ & 0,59 & $\mathrm{~b}$ & 0,37 & $\mathrm{~b}$ & 0,31 & $\mathrm{~b}$ & 0,23 & $\mathrm{~b}$ & 0,22 & $\mathrm{~b}$ & 0,14 & $\mathrm{~b}$ & 0,14 & $\mathrm{~b}$ \\
\hline
\end{tabular}

Verschillende letters in een kolom duiden op significante verschillen $(a<0,05)$

Op alle stroken geeft de standaard dwarsstroomspuit de hoogste drift. Op de strook 41/2-51/2 m behorende bij een $3 \mathrm{~m}$ teeltvrije zone was dit 6,34\%. De HSS-CF -A geeft op alle stroken een significant lagere drift. Op 41/2-51/2 m werd met de HSS-CF -A 0,59\% drift gevonden.

\subsubsection{HSS-CF -B en HSS-CF -C}

De gemiddelde drift per spuittechniek tijdens bespuitingen in de volblad situatie (BBCH 90) staat weergegeven in Figuur 3.2 en in Tabel 3.2.

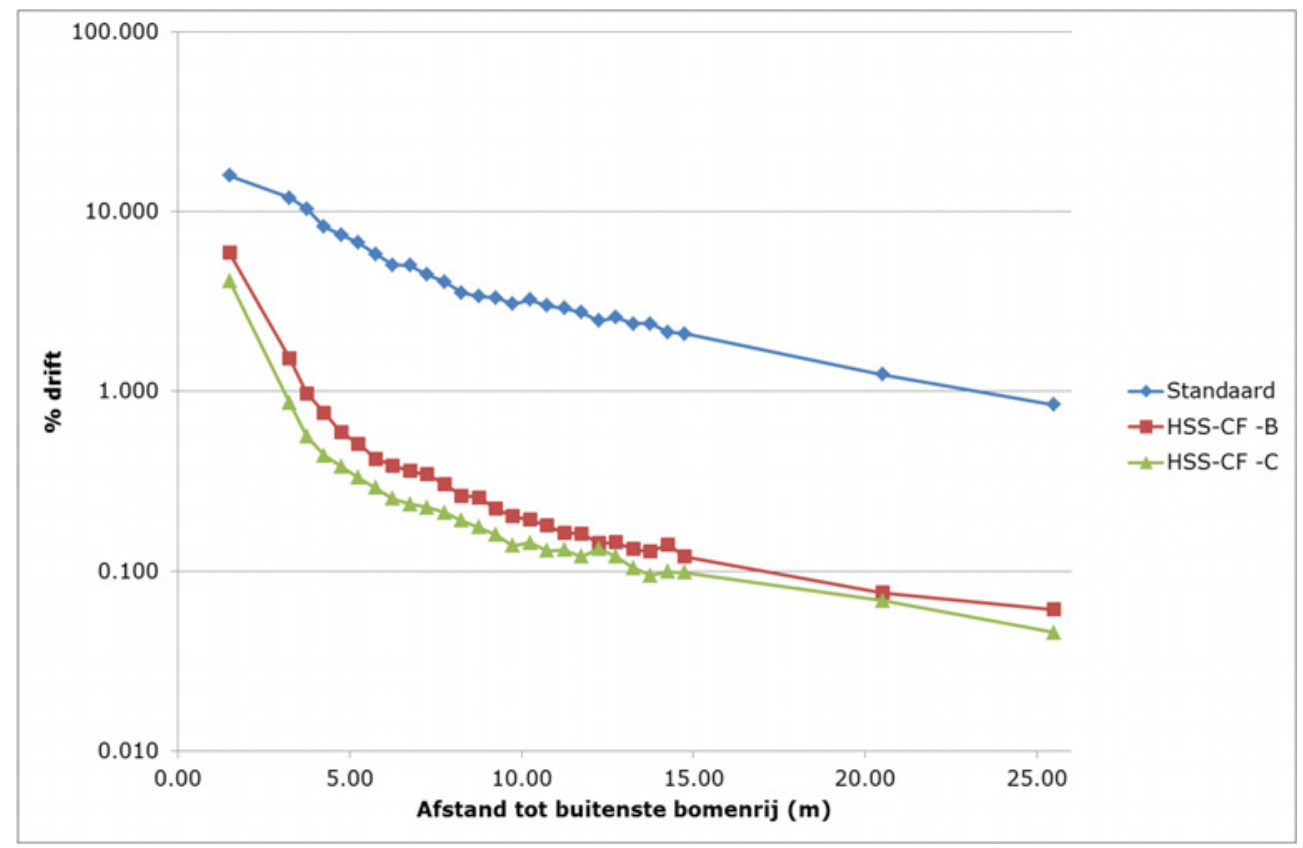

Figuur 3.2 Gemiddelde drift (\% van verspoten hoeveelheid spuitvloeistof per oppervlakte-eenheid) op verschillende afstanden vanaf het hart van de buitenste bomenrij bij bespuitingen van appelbomen in de volblad situatie (BBCH 90) met een standaard dwarsstroomspuit (Munckhof met ATR lila werveldoppen), een H.S.S. CF met lage luchtinstelling en 1-zijdige bespuiting van de buitenste bomenrij met TVI8001 venturi werveldoppen (HSS-CF -B) en een H.S.S. CF met lage luchtinstelling met 1-zijdige bespuiting van de buitenste bomenrij met TVI8001 venturi werveldoppen en automatische hoekverdraaiing van de spuitmonden (HSS-CF-C). 
In Figuur 3.2 en Tabel 3.2 is te zien dat de standaard dwarsstroomspuit de meeste drift geeft. De HSS-CF -B geeft duidelijk minder drift. De HSS-CF -C geeft de laagste drift. Dit is verder uitgewerkt in Tabel 3.4 voor de verschillende evaluatiestroken.

Tabel 3.4 Gemiddelde drift (\% van verspoten hoeveelheid spuitvloeistof per oppervlakte-eenheid) op de evaluatiestroken overeenkomend met teeltvrije zones van $3 m, 41 / 2 m, 6 m$ en $9 m$ bij bespuitingen van appelbomen in het volblad stadium (BBCH 90) met een standaard dwarsstroomspuit (Munckhof met ATR lila werveldoppen), een H.S.S. CF met lage luchtinstelling en 1-zijdige bespuiting van de buitenste bomenrij met TVI8001 venturi werveldoppen (HSS-CF -B) en een H.S.S. CF met lage luchtinstelling met 1-zijdige bespuiting van de buitenste bomenrij met TVI8001 venturi werveldoppen en automatische hoekverdraaiing van de spuitmonden (HSS-CF -C).

\begin{tabular}{|c|c|c|c|c|c|c|c|c|c|c|c|c|c|c|c|c|}
\hline \multirow{3}{*}{$\begin{array}{l}\text { Techniek } \\
\text { Standaard }\end{array}$} & \multicolumn{16}{|c|}{ Afstand tot buitenste bomenrij ( $\mathrm{m}$ ) } \\
\hline & \multicolumn{4}{|c|}{$3 \mathrm{~m}$ teeltvrij } & \multicolumn{4}{|c|}{$41 / 2 \mathrm{~m}$ teeltvrij } & \multicolumn{4}{|c|}{$6 \mathrm{~m}$ teeltvrij } & \multicolumn{4}{|c|}{$9 \mathrm{~m}$ teeltvrij } \\
\hline & \multicolumn{2}{|c|}{ 3-7 } & \multicolumn{2}{|c|}{$41 / 2-51 / 2$} & \multicolumn{2}{|c|}{$41 / 2-81 / 2$} & \multicolumn{2}{|c|}{$6-7$} & \multicolumn{2}{|c|}{$6-10$} & \multicolumn{2}{|c|}{$71 / 2-81 / 2$} & \multicolumn{2}{|c|}{$9-13$} & \multicolumn{2}{|c|}{$101 / 2-111 / 2$} \\
\hline HSS-CF - B & 0,69 & $\mathrm{~b}$ & 0,55 & $\mathrm{~b}$ & 0,40 & $\mathrm{~b}$ & 0,37 & $\mathrm{~b}$ & 0,29 & $\mathrm{~b}$ & 0,28 & $b$ & 0,18 & $\mathrm{~b}$ & 0,17 & $\mathrm{~b}$ \\
\hline HSS-CF - C & 0,42 & c & 0,36 & c & 0,27 & c & 0,24 & $\mathrm{~b}$ & 0,20 & $\mathrm{~b}$ & 0,20 & $\mathrm{~b}$ & 0,13 & $b$ & 0,13 & $b$ \\
\hline
\end{tabular}

Verschillende letters in een kolom duiden op significante verschillen $(a<0,05)$.

Op alle stroken geeft de standaard dwarsstroomspuit de hoogste drift. Op de strook 41/2-51/2 m behorende bij een $3 \mathrm{~m}$ teeltvrije zone was dit 7,09\%. De HSS-CF -B geeft op alle stroken een significant lagere drift. Op 41/2-51/2 m werd bij de HSS-CF -B 0,55\% drift gevonden. De laagste drift wordt gevonden bij de HSS-CF -C. Op alle stroken is de drift van de HSS-CF -C significant lager dan de standaard spuit. Op de strook 41/2-51/2 m werd bij de HSS-CF -C 0,36\% drift gevonden. Ten opzichte van de HSS-CF -B is dat alleen op de stroken behorende bij een $3 \mathrm{~m}$ teeltvrije zone (3-7 m, $4 \frac{1}{2}-51 / 2 \mathrm{~m}$ ) en de strook $4 \frac{1}{2}-81 \frac{1}{2} \mathrm{~m}$ behorende bij een $4 \frac{1}{2} \mathrm{~m}$ teeltvrije zone significant. 


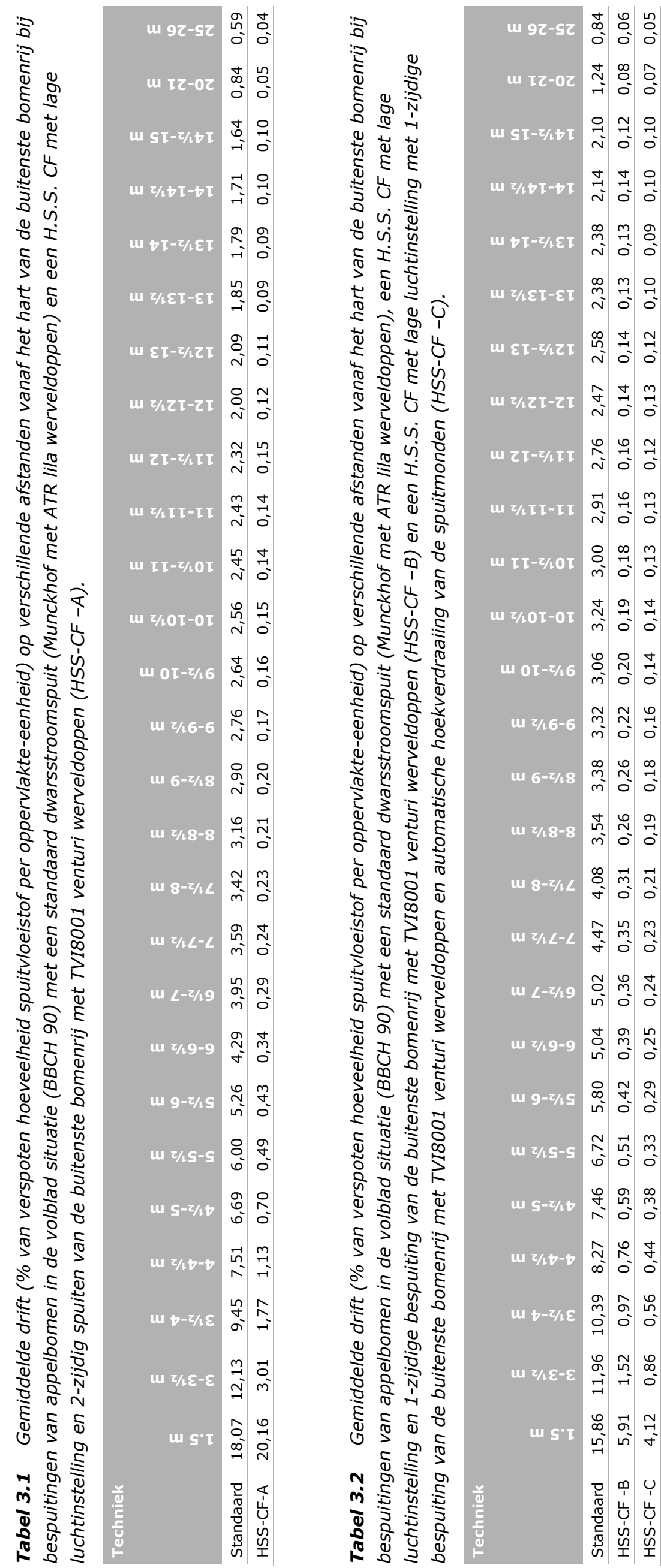




\subsection{Drift naar de lucht}

\subsubsection{HSS-CF -A}

De gemiddelde drift naar de lucht per spuittechniek tijdens bespuitingen in de volblad situatie (BBCH 90) staat weergegeven in Figuur 3.3 en in Tabel 3.5.

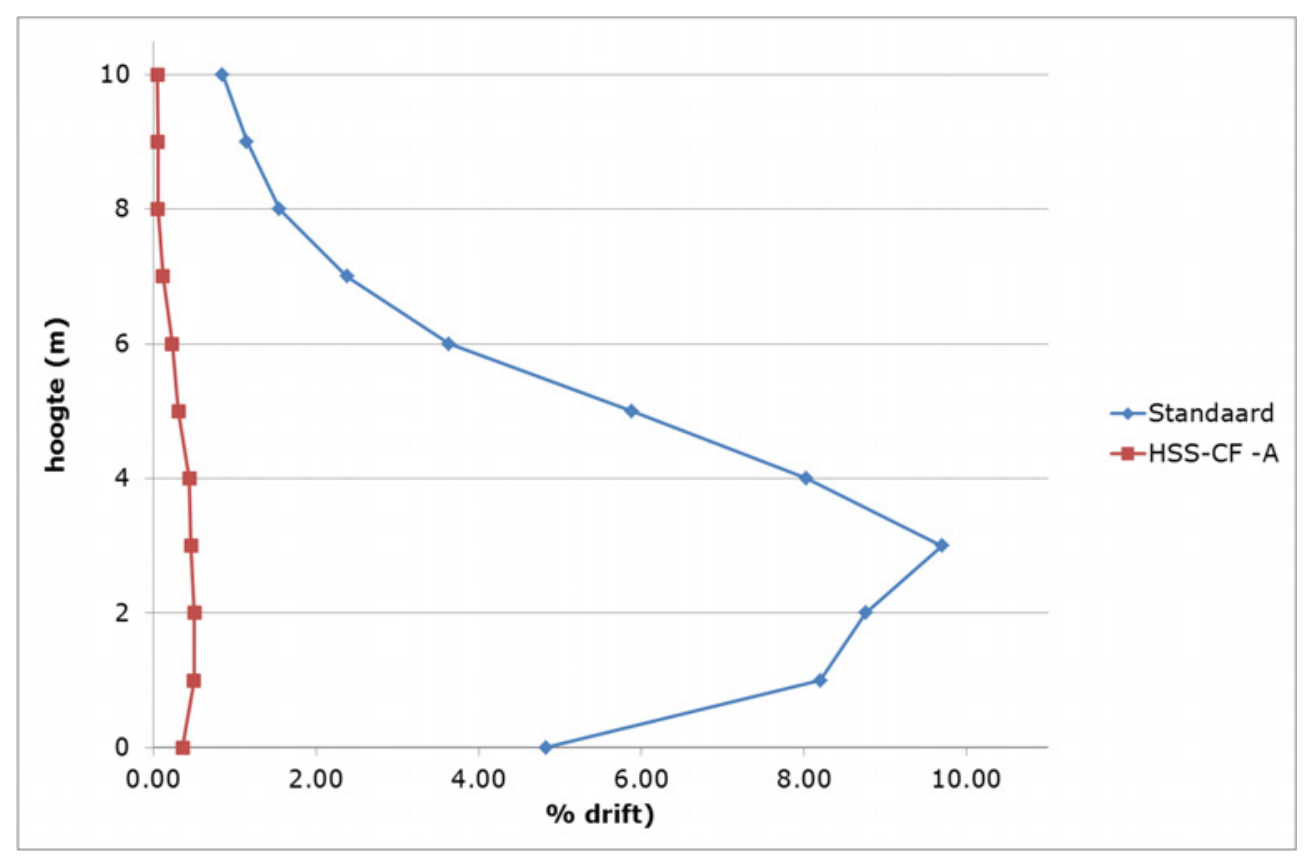

Figuur 3.3 Gemiddelde drift (\% van verspoten hoeveelheid spuitvloeistof per oppervlakte-eenheid) op verschillende hoogtes op 71/2 $m$ afstanden vanaf het hart van de buitenste bomenrij bij bespuitingen van appelbomen in de volblad situatie (BBCH 90) met een standaard dwarsstroomspuit (Munckhof met ATR lila werveldoppen) en een HSS-CF met lage luchtinstelling en 2-zijdig spuiten van de buitenste bomenrij met TVI8001 venturi werveldoppen (HSS-CF -A).

In Figuur 3.3 en Tabel 3.5 is te zien dat de standaard dwarsstroomspuit de meeste drift naar de lucht geeft. De HSS-CF -A geeft een duidelijk lagere drift. Bij de standaard bespuiting wordt op $10 \mathrm{~m}$ hoogte nog $0,85 \%$ drift gevonden. Dit betekent dat er bij de standaardbespuiting op de hoogste $(10 \mathrm{~m})$ collector $1,6 \%$ gevonden werd van de opgevangen hoeveelheid over de collectoren $0-9 \mathrm{~m}$. Dit is minder dan $10 \%$ van de totale hoeveelheid (ISO22866) waarmee aangegeven is dat er hoog genoeg gemeten is. Bij de HSS-CF -A wordt op $10 \mathrm{~m}$ bijna $(<0,1 \%)$ geen drift meer gemeten, wat $1,6 \%$ is van de totale hoeveelheid over 0-9 m hoogte waarmee ook voor deze techniek aangegeven is dat er hoog genoeg gemeten is.

De resultaten van de driftmetingen naar de lucht zijn verder uitgewerkt in Tabel 3.7.

Tabel 3.7 Gemiddelde drift (\% van verspoten hoeveelheid spuitvloeistof per oppervlakte-eenheid) op verschillende hoogtes op 71/2 $m$ afstanden vanaf het hart van de buitenste bomenrij bij bespuitingen van appelbomen in de volblad situatie (BBCH 90) met een standaard dwarsstroomspuit (Munckhof met ATR lila werveldoppen) en een H.S.S. CF met lage luchtinstelling en 2-zijdig spuiten van de buitenste bomenrij met TVI8001 venturi werveldoppen (HSS-CF -A).

\begin{tabular}{|c|c|c|c|c|c|c|c|c|}
\hline \multirow{3}{*}{$\begin{array}{l}\text { techniek } \\
\text { Standaard }\end{array}$} & \multicolumn{8}{|c|}{$\%$ drift op hoogte $(\mathrm{m})$} \\
\hline & \multicolumn{2}{|c|}{$0-3$} & \multicolumn{2}{|c|}{ 3-6 } & \multicolumn{2}{|c|}{$6-10$} & \multicolumn{2}{|c|}{$0-10$} \\
\hline & 7,87 & $\mathrm{a}$ & 6,81 & $\mathrm{a}$ & 1,91 & $\mathrm{a}$ & 4,99 & a \\
\hline
\end{tabular}

Verschillende letters in een kolom duiden op significante verschillen $(a<0,05)$. 
Op alle hoogtes geeft de standaard dwarsstroomspuit de hoogste drift naar de lucht. Gemiddeld over de 0-10 m hoogte was de drift naar de lucht op 7,5 m van de buitenste bomenrij voor de standaard dwarsstroomspuit 4,99\%. De drift naar de lucht bij de HSS-CF -A is op alle hoogtes significant lager dan van de standaard dwarsstroomspuit. Over 0-10 m hoogte werd bij de HSS-CF -A 0,28\% drift naar de lucht gevonden.

\subsubsection{HSS-CF -B en HSS-CF -C}

De gemiddelde drift naar de lucht per spuittechniek tijdens bespuitingen in de volblad situatie (BBCH 90) staat weergegeven in Figuur 3.4 en in Tabel 3.6.

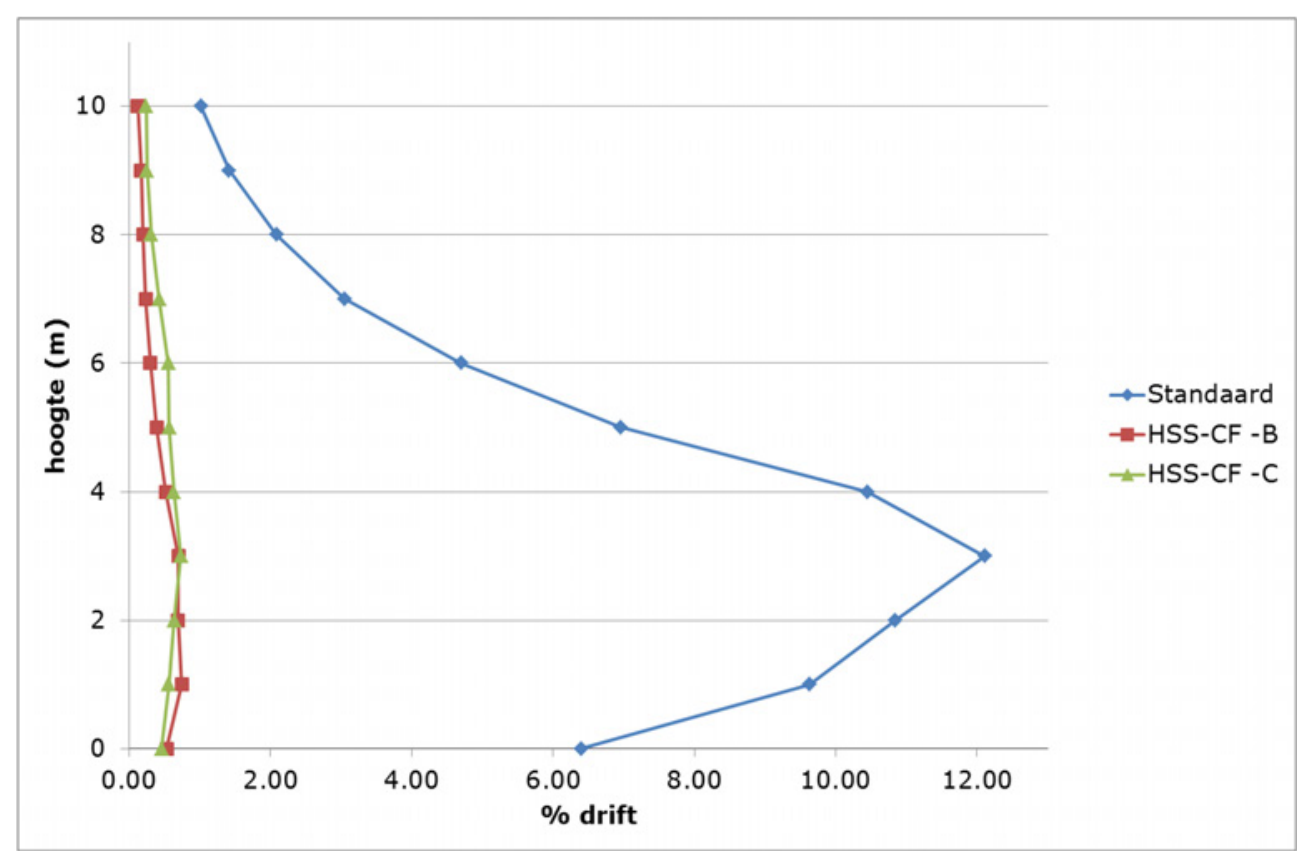

Figuur 3.4 Gemiddelde drift (\% van verspoten hoeveelheid spuitvloeistof per oppervlakte-eenheid) op verschillende hoogtes op 71/2 $m$ afstanden vanaf het hart van de buitenste bomenrij bij bespuitingen van appelbomen in de volblad situatie (BBCH 90) met een standaard dwarsstroomspuit (Munckhof met ATR lila werveldoppen), een H.S.S. CF met lage luchtinstelling en 1-zijdige bespuiting van de buitenste bomenrij met TVI8001 venturi werveldoppen (HSS-CF -B) en een H.S.S. CF met lage luchtinstelling met 1-zijdige bespuiting van de buitenste bomenrij met TVI8001 venturi werveldoppen en automatische hoekverdraaiing van de spuitmonden (HSS-CF -C).

In Figuur 3.4 en Tabel 3.6 is te zien dat de standaard dwarsstroomspuit de meeste drift naar de lucht geeft. De HSS-CF -B en HSS-CF -C geeft bij beide instellingen een duidelijk lagere drift naar de lucht. Tussen de twee instellingen op de HSS-CF zit weinig verschil.

Bij de standaard bespuiting wordt op $10 \mathrm{~m}$ hoogte nog 1,02\% drift naar de lucht gevonden. Bij de HSS-CF wordt bij beide instellingen op $10 \mathrm{~m}$ hoogte $0,12 \%$ en $0,24 \%$ drift naar de lucht gevonden. In alle drie gevallen is de drift op de hoogste $(1 \mathrm{~m})$ collector resp. $1,5 \%, 2,8 \%$ en $4,7 \%$ van de opgevangen hoeveelheid over de collectoren 0-9 m hoogte. Dit is minder dan $10 \%$ van de totale hoeveelheid (ISO22866) waarmee aangegeven is dat er in alle drie gevallen hoog genoeg gemeten is.

De resultaten van de driftmetingen naar de lucht zijn verder uitgewerkt in Tabel 3.8. 
Tabel 3.8 Gemiddelde drift (\% van verspoten hoeveelheid spuitvloeistof per oppervlakte-eenheid) op verschillende hoogtes op $71 / 2 m$ afstanden vanaf het hart van de buitenste bomenrij bij bespuitingen van appelbomen in de volblad situatie (BBCH 90) met een standaard dwarsstroomspuit (Munckhof met ATR lila werveldoppen), een H.S.S. CF met lage luchtinstelling en 1-zijdige bespuiting van de buitenste bomenrij met TVI8001 venturi werveldoppen (HSS-CF -B) en een H.S.S. CF met lage luchtinstelling met 1-zijdige bespuiting van de buitenste bomenrij met TVI8001 venturi werveldoppen en automatische hoekverdraaiing van de spuitmonden (HSS-CF -C).

\begin{tabular}{|c|c|c|c|c|c|c|c|c|}
\hline \multirow{3}{*}{$\begin{array}{l}\text { Techniek } \\
\text { Standaard }\end{array}$} & \multicolumn{8}{|c|}{$\%$ drift op hoogte $(\mathrm{m})$} \\
\hline & \multicolumn{2}{|c|}{$0-3$} & \multicolumn{2}{|c|}{$3-6$} & \multicolumn{2}{|c|}{$6-10$} & \multicolumn{2}{|c|}{$0-10$} \\
\hline & 9,75 & a & 8,55 & a & 2,46 & a & 6,24 & a \\
\hline HSS-CF -C & 0,60 & $b$ & 0,62 & b & 0,36 & $b$ & 0,49 & $b$ \\
\hline
\end{tabular}

Verschillende letters in een kolom duiden op significante verschillen $(a<0,05)$

Op alle hoogtes geeft de standaard dwarsstroomspuit de hoogste drift naar de lucht. Gemiddeld over de 0-10 m hoogte was de drift naar de lucht op 7,5 m van de buitenste bomenrij voor de standaard dwarsstroomspuit 6,24\%. De HSS-CF -B en de HSS-CF -C geven over alle hoogtes significant minder drift naar de lucht. Gemiddeld over 0-10 m was de drift naar de lucht respectievelijk 0,42\% en 0,49\%. Het onderlinge verschil tussen HSS-C -B en HSS- CF -C was niet significant. 


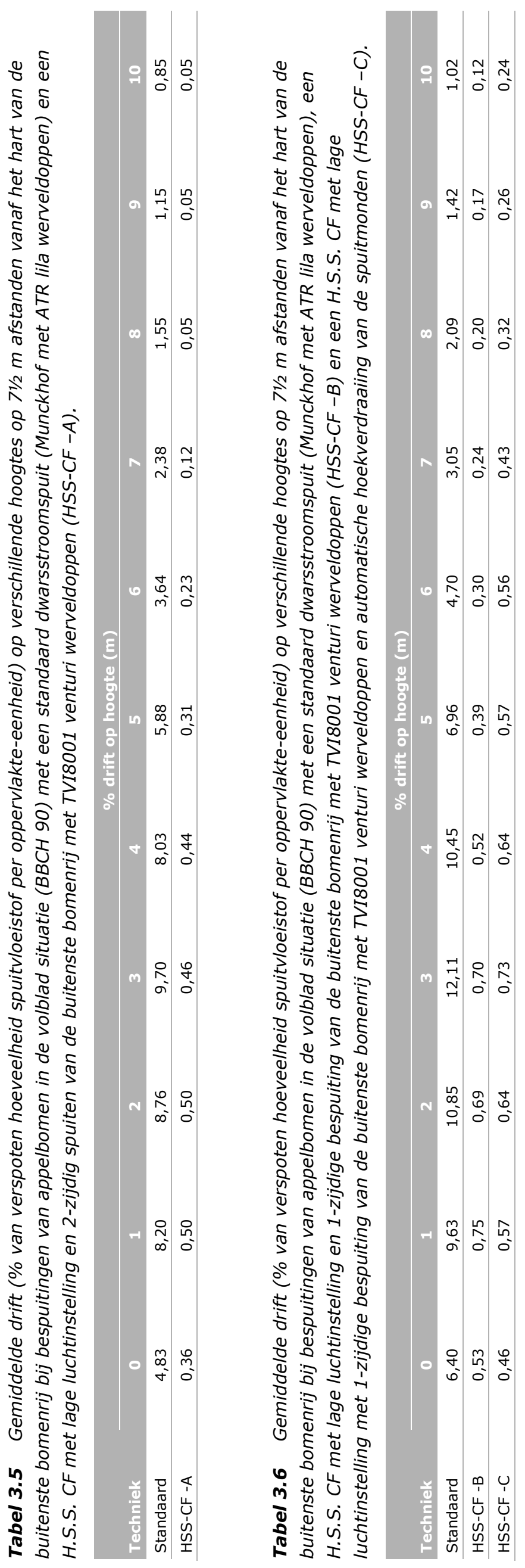




\section{Discussie}

\section{Driftreductie}

H.S.S. CF met lage luchtinstelling en 2-zijdig spuiten van de buitenste bomenrij met TVI8001 venturi werveldoppen (HSS-CF -A)

Ten opzichte van de standaardbespuiting met de standaard boomgaardspuit geeft de H.S.S. CF met lage luchtinstelling en 2-zijdig spuiten van de buitenste bomenrij met TVI8001 venturi werveldoppen (HSS-CF -A) naar de grond op alle stroken een significantie driftreductie tussen $85,2 \%-94,3 \%$. Bij een teeltvrije zone van $3 \mathrm{~m}$ wordt op de strook 41/2-51/2 m met de H.S.S. CF met lage luchtinstelling en 2-zijdig spuiten van de buitenste bomenrij met TVI8001 venturi werveldoppen (HSS-CF -A) een driftreductie gevonden van 90,6\%. Bij de drift naar de lucht gemiddeld over 0-10 m hoogte op 7,5 m van de laatste bomenrij wordt met de HSS-CF -A een significante driftreductie van $94,4 \%$ gevonden.

Tabel 4.1 Gemiddelde driftreductie (\%) H.S.S. CF met lage luchtinstelling en 2-zijdig spuiten van de buitenste bomenrij met TVI8001 venturi werveldoppen ten opzichte van de referentie spuit (Munckhof dwarsstroomspuit voorzien van ATR Lila werveldoppen) op de verschillende evaluatiestroken (overeenkomend met teeltvrije zones van $3 m, 41 / 2 m, 6 m$ en $9 m$ ) en naar de lucht (gemiddeld over 0-10 m hoogte) op 7,5 $\mathrm{m}$ van de buitenste bomenrij bij bespuitingen in appelbomen in het volblad stadium (BBCH 90).

\begin{tabular}{|c|c|c|c|c|c|c|c|c|c|}
\hline \multirow[b]{3}{*}{ Techniek } & \multicolumn{9}{|c|}{ Driftreductie $(\%)$ op } \\
\hline & \multicolumn{2}{|c|}{$3 \mathrm{~m}$ teeltvrij } & \multicolumn{2}{|c|}{$41 / 2 \mathrm{~m}$ teeltvrij } & \multicolumn{2}{|c|}{$6 \mathrm{~m}$ teeltvrij } & \multicolumn{2}{|c|}{$9 \mathrm{~m}$ teeltvrij } & \multirow{2}{*}{$\begin{array}{l}\text { Lucht } \\
0-10 \mathrm{~m}\end{array}$} \\
\hline & $3-7$ & $41 / 2-51 / 2$ & $41 / 2-81 / 2$ & $6-7$ & $6-10$ & $71 / 2-81 / 2$ & 9-13 & $101 / 2-11 \frac{1 / 2}{2}$ & \\
\hline Standaard & $*$ & $*$ & * & * & * & $*$ & $*$ & $*$ & $*$ \\
\hline HSS-CF - A & 85,2 & 90,6 & 92,0 & 92,4 & 93,1 & 93,3 & 94,1 & 94,3 & 94,4 \\
\hline
\end{tabular}

H.S.S. CF met lage luchtinstelling en 1-zijdige bespuiting van de buitenste bomenrij met TVI8001 venturi werveldoppen (HSS-CF -B) en een H.S.S. CF met lage luchtinstelling met 1-zijdige bespuiting van de buitenste bomenrij met TVI8001 venturi werveldoppen en automatische hoekverdraaiing van de spuitmonden (HSS-CF-C)

Ten opzichte van de standaardbespuiting met de standaard boomgaardspuit geeft de H.S.S. CF met lage luchtinstelling en 1-zijdige bespuiting van de buitenste bomenrij met TVI8001 venturi werveldoppen (HSS-CF -B) op alle stroken significante driftreducties tussen 90,9\%-94,2\%. Bij een teeltvrije zone van $3 \mathrm{~m}$ wordt op de strook 41/2-51/2 m met de H.S.S. CF met lage luchtinstelling en 1-zijdige bespuiting van de buitenste bomenrij met TVI8001 venturi werveldoppen (HSS-CF -B) een driftreductie gevonden van 92,2\%. Bij de drift naar de lucht gemiddeld over 0-10 m hoogte op 7,5 m van de buitenste bomenrij wordt met de HSS-CF -B een significante driftreductie gevonden van 93,3\%.

Ten opzichte van de standaardbespuiting met de standaard boomgaardspuit geeft de H.S.S. CF met lage luchtinstelling met 1-zijdige bespuiting van de buitenste bomenrij met TVI8001 venturi werveldoppen en automatische hoekverdraaiing van de spuitmonden (HSS-CF -C) op alle stroken significante driftreducties tussen $94,5 \%-95,6 \%$. Bij een teeltvrije zone van $3 \mathrm{~m}$ wordt op de strook $4 \frac{1}{2}-51 / 2 \mathrm{~m}$ met de H.S.S. CF met lage luchtinstelling met 1-zijdige bespuiting van de buitenste bomenrij met TVI8001 venturi werveldoppen en automatische hoekverdraaiing van de spuitmonden (HSS-CF -C) een driftreductie gevonden van 95,0\%. Bij de drift naar de lucht gemiddeld over 0-10 m hoogte op 7,5 m van de laatste bomenrij wordt met de HSS-CF -C een significante driftreductie gevonden van $92,1 \%$. 
Tabel 4.2 Gemiddelde driftreductie (\%)H.S.S. CF met lage luchtinstelling en 1-zijdige bespuiting van de buitenste bomenrij met TVI8001 venturi werveldoppen (HSS-CF -B) en een H.S.S. CF met lage luchtinstelling met 1-zijdige bespuiting van de buitenste bomenrij met TVI8001 venturi werveldoppen en automatische hoekverdraaiing van de spuitmonden (HSS-CF -C) ten opzichte van de referentie spuit (Munckhof dwarsstroomspuit voorzien van ATR Lila werveldoppen) op de verschillende evaluatiestroken (overeenkomend met teeltvrije zones van $3 \mathrm{~m}, 41 / 2 \mathrm{~m}, 6 \mathrm{~m}$ en $9 \mathrm{~m}$ ) en naar de lucht (gemiddeld over 0-10 m hoogte) op 7,5 $\mathrm{m}$ van de buitenste bomenrij bij bespuitingen in appelbomen in het volblad stadium (BBCH 90).

\begin{tabular}{|c|c|c|c|c|c|c|c|c|c|}
\hline \multirow[b]{3}{*}{ Techniek } & \multicolumn{9}{|c|}{ Driftreductie ( $\%)$ op } \\
\hline & \multicolumn{2}{|c|}{$3 \mathrm{~m}$ teeltvrij } & \multicolumn{2}{|c|}{$41 / 2 \mathrm{~m}$ teeltvrij } & \multicolumn{2}{|c|}{$6 \mathrm{~m}$ teeltvrij } & \multicolumn{2}{|c|}{9 m teeltvrij } & \multirow{2}{*}{$\begin{array}{c}\text { Lucht } \\
0-10 \mathrm{~m}\end{array}$} \\
\hline & $3-7$ & $41 / 2-51 / 2$ & $41 / 2-81 / 2$ & $6-7$ & $6-10$ & $71 / 2-81 / 2$ & $9-13$ & $101 / 2-111 / 2$ & \\
\hline HSS-CF -B & 90,9 & 92,2 & 92,4 & 92,6 & 92,7 & 92,6 & 94,0 & 94,2 & 93,3 \\
\hline HSS-CF -C & 94,5 & 95,0 & 95,0 & 95,1 & 95,0 & 94,7 & 95,4 & 95,6 & 92,1 \\
\hline
\end{tabular}

\section{Effect van lagere luchtinstelling}

Eerder onderzoek naar het effect van een lage luchtinstelling bij een Munckhof dwarsstroomspuit is uitgevoerd door Wenneker et al. (2004). In het volblad stadium vonden zij dat bij gebruik van een venturi spleetdop (Lechler 90-01C; spuitdruk 5 bar) en standaard tweezijdig spuiten van de buitenste bomenrij en de ventilator in de hoge stand (zomerstand) een driftreductie ten opzichte van de standaard spuitdop (Albuz ATR lila, 7 bar) gaf van 55\% op 4,5-5,5 m afstand van de laatste bomenrij. Bij gebruik van de ventilator in de lage stand (winterstand) werd met de venturidop en tweezijdig spuiten van de laatste bomenrij een driftreductie van $78 \%$ gemeten. Werd de buitenste bomenrij eenzijdig gespoten dan vond Wenneker et al (2004) in de volblad situatie en de ventilator in de hoge stand met de venturidop een driftreductie van $88 \%$ op 4,5 - 5,5 m afstand van de laatste bomenrij. Deze combinatie is de uitgangssituatie voor de $90 \%$ driftreductieklasse in de fruitteelt en beperking van de teeltvrije zone tot $3 \mathrm{~m}$ (I\&M, 2012). Door de ventilator in de lage stand te gebruiken werd bij de venturidop in combinatie met éénzijdig spuiten van de buitenste bomenrij $96 \%$ driftreductie gerealiseerd.

Door het gebruik van een lager niveau van luchtondersteuning werd bij de metingen met een Munckhof dwarsstroomspuit (Wenneker et al., 2004) de driftreductie bij tweezijdig spuiten en eenzijdig spuiten van de laatste bomenrij bij de venturidop verbeterd waardoor de driftreductie met een klasse verhoogd werd, resp. van $50 \%$ naar $75 \%$ en van $90 \%$ naar $95 \%$. Een soortgelijk effect treedt in de gepresenteerde resultaten van de H.S.S. CF ook op. Door een lagere luchtondersteuning met een ventilator toerental van $1800 \mathrm{rpm}$ kan de H.S.S. CF met een 90\% spuitdop in de buitenste bomenrij tweezijdig gebruikt worden en toch $90 \%$ driftreductie geven. Door de aangepaste spuitmond instelling kan de H.S.S. CF met lage luchtondersteuning (1800 rpm), een 90\% spuitdop en eenzijdig spuiten van de buitenste bomenrij $95 \%$ driftreductie geven.

\section{Effect van automatische hoekverdraaiing van de spuitmonden}

Op alle stroken wordt door gebruik van blaasmondverstelling (HSS- CF -C) een hogere driftreductie gevonden dan zonder blaasmondverstelling (HSS-CF -B). Op de stroken 3-7 m, 41/2-51/2 m en $41 / 2-81 / 2 \mathrm{~m}$ is dat verschil statistisch significant. Mogelijk kan door optimalisatie van de afstelling de driftreductie verder verhoogd worden.

\section{Effect van doptypen}

Uit de in deze rapportage gepresenteerde driftmetingen van de H.S.S. CF boomgaardspuit blijkt dat de constructie van de H.S.S. CF boomgaardspuit en de uitgebrachte hoeveelheid lucht ertoe leidt dat met de H.S.S. CF dwarsstroomspuit uitgerust met 90\% drift reducerende spuitdoppen de buitenste bomenrij van twee kanten bespoten kan worden en toch in de DRT90 klasse valt. Hierdoor is dit spuittype met tweezijdig spuiten van de buitenste bomenrij in driftreductie gelijkwaardig aan een standaard dwarsstroomspuit met vollucht en eenzijdig spuiten van de buitenste bomenrij. Hieruit blijkt dat bij gebruik van een lage luchtinstelling met H.S.S. Drift Control een toename in driftreducerend effect optreedt waardoor de buitenste bomenrij tweezijdig gespoten kan worden. De driftreductie en daarmee de indeling van de spuittechniek in DRT-klassen is ook afhankelijk van de gebruikte spuitdop. Uit eerder uitgevoerd onderzoek naar het effect van driftreducerende doppen 
(DRD) met de op- en zijwaarts spuitende referentiespuit, waarbij ook de spuittechniek leidend is voor het behalen van de driftreductie, bleek ook dat bij gebruik van spuitdoppen uit de verschillende lagere en hogere DRD-klasse, de indeling van de spuittechniek in een respectievelijk lagere dan wel hogere DRT-klasse (bij eenzijdig spuiten van de buitenste bomenrij) was (Zande et al., 2012; Stallinga et al., 2011a, 2011b). Gebruik van een dwarsstroomspuit in combinatie met eenzijdig spuiten van de buitenste bomenrij en spuitdoppen uit DRD-klasse 50\%, 75\% en 90\%, zijn ingedeeld in respectievelijk DRT-klasse $50 \%$, 75\% en $90 \%$ (TCT, 2017). Bij gebruik van een dwarsstroomspuit in combinatie spuitdoppen uit DRD-klasse 95\% doppen, is bij een $3 \mathrm{~m}$ teeltvrije zone de driftreductie lager dan $95 \%$, maar bij een teeltvrije zone van 4,5 m werd wel meer dan 95\% driftreductie gemeten. In overeenkomst met de uitkomsten van dit en eerder uitgevoerd driftonderzoek kan dan de H.S.S. CF boomgaardspuit met gebruik van spuitdoppen uit de andere driftreductie klassen ook ingedeeld worden in de driftreducerende techniek klassen (DRT):

- 50\% klasse, wanneer uitgevoerd met H.S.S. Drift Control met $1800 \mathrm{rpm}$ ventilator (lage lucht instelling) en 2-zijdig spuiten van de buitenste bomenrij met $50 \%$ driftreducerende spuitdop;

- 75\% klasse, wanneer uitgevoerd met H.S.S. Drift Control met 1800 rpm ventilator (lage lucht instelling) en 2-zijdig spuiten van de buitenste bomenrij met 75\% driftreducerende spuitdop;

- 95\% klasse, wanneer uitgevoerd met H.S.S. Drift Control met $1800 \mathrm{rpm}$ ventilator (lage lucht instelling) en 2-zijdig spuiten van de buitenste bomenrij met $95 \%$ driftreducerende spuitdop bij een $4,5 \mathrm{~m}$ teeltvrije zone.

Uit deze driftmetingen van de H.S.S. CF boomgaardspuit blijkt ook dat door gebruik van de H.S.S. AWC (AWC = Automatic Wind Control) met automatische hoekverdraaiing van de blaasmonden op de H.S.S. CF boomgaardspuit de driftreductie bij eenzijdig spuiten van de buitenste bomenrij met een $90 \%$ driftreducerende spuitdop de driftreductie van het systeem als geheel uitkomt op een driftreductie van $95 \%$ en daardoor indeling in de DRT klasse 95\%. De constructie van de H.S.S. CF boomgaardspuit en de daarmee uitgebrachte luchthoeveelheid bij $1800 \mathrm{rpm}$ ventilator toerental en het gebruik van H.S.S. AWC (AWC = Automatic Wind Control) met automatische hoekverdraaiing van de blaasmonden zorgen er dus voor dat met de H.S.S. CF boomgaardspuit een gebruikte $90 \%$ driftreducerende dop in de $95 \%$ driftreductieklasse valt. Dit verhogen van de driftreductieklasse van een dop met één driftreductieklasse is een eigenschap van het spuitsysteem H.S.S. CF boomgaardspuit met H.S.S. AWC (AWC = Automatic Wind Control) met automatische hoekverdraaiing van de blaasmonden.

In overeenkomst met de uitkomsten van dit en eerder uitgevoerd driftonderzoek naar het effect van doptypen uit de verschillende driftreducerende dop (DRD) klassen kan de H.S.S. CF boomgaardspuit met H.S.S. AWC (Automatic Wind Control) met 1800 rpm ventilator (lage lucht instelling) en automatische hoekverdraaiing van de spuitmonden voor de verschillende DRD klassen ook ingedeeld worden in de driftreducerende techniek klasse (DRT):

- $75 \%$ klasse, wanneer uitgevoerd met H.S.S. Drift Control en H.S.S. AWC (Automatic Wind Control) met $1800 \mathrm{rpm}$ ventilator (lage lucht instelling) en eenzijdig spuiten van de buitenste bomenrij met $50 \%$ driftreducerende spuitdop en automatische hoekverdraaiing van de spuitmonden;

- $90 \%$ klasse, wanneer uitgevoerd met H.S.S. Drift Control en H.S.S. AWC (Automatic Wind Control) met $1800 \mathrm{rpm}$ ventilator (lage lucht instelling) en eenzijdig spuiten van de buitenste bomenrij met $75 \%$ driftreducerende spuitdop en automatische hoekverdraaiing van de spuitmonden;

- 97,5\% klasse, wanneer uitgevoerd met H.S.S. Drift Control en H.S.S. AWC (Automatic Wind Control) met $1800 \mathrm{rpm}$ ventilator (lage lucht instelling) en eenzijdig spuiten van de buitenste bomenrij met $95 \%$ driftreducerende spuitdop en automatische hoekverdraaiing van de spuitmonden en een 4,5 m teeltvrije zone. 


\section{$5 \quad$ Conclusie}

Tijdens bespuitingen van een appelboomgaard in het volblad stadium (BBCH 90) met een H.S.S. CF serie dwarsstroomspuit uitgevoerd met H.S.S. Drift Control en H.S.S. AWC (Automatic Wind Control) zijn driftmetingen in vergelijking met een referentie boomgaard bespuiting uitgevoerd.

De resultaten van de driftmetingen geven bij een $3 \mathrm{~m}$ teeltvrije zone op de strook 41/2-51/2 $\mathrm{m}$ vanaf de buitenste bomenrij de volgende driftreductie voor de verschillende instellingen van de H.S.S. CF:

De H.S.S. CF serie uitgevoerd met H.S.S. Drift Control met lage lucht instelling (1800 rpm ventilator) en 2-zijdig spuiten van de buitenste bomenrij met 90\% driftreducerende spuitdop (TVI8001 op 7 bar) geeft $\mathbf{9 0 , 6 \%}$ driftreductie. Daarmee kan deze spuittechniek in driftreducerende techniek (DRT) klasse 90 ingedeeld kunnen worden.

De H.S.S. CF serie uitgevoerd met H.S.S. Drift Control met lage lucht instelling (1800 rpm ventilator) en eenzijdig spuiten van de buitenste bomenrij met $90 \%$ driftreducerende spuitdop (TVI8001 op 7 bar) geeft 92,2\% driftreductie. Daarmee kan deze spuittechniek in driftreducerende techniek (DRT) klasse 90 ingedeeld kunnen worden.

H.S.S. CF serie uitgevoerd met H.S.S. Drift Control en H.S.S. AWC (Automatic Wind Control) met lage lucht instelling (1800 rpm ventilator) en eenzijdig spuiten van de buitenste bomenrij met $90 \%$ driftreducerende spuitdop (TVI8001 op 7 bar) en automatische hoekverdraaiing van de spuitmonden geeft $\mathbf{9 5 . 0 \%}$ driftreductie. Daarmee kan deze spuittechniek in driftreducerende techniek (DRT) klasse 95 ingedeeld kunnen worden.

De driftreductie naar de lucht, gemiddeld over 0-10 m hoogte, op 7,5 $\mathrm{m}$ van de laatste bomenrij is voor de H.S.S. CF serie uitgevoerd met H.S.S. Drift Control met lage lucht instelling (1800 rpm ventilator) en 2-zijdig spuiten van de buitenste bomenrij met $90 \%$ driftreducerende spuitdop (TVI8001 op 7 bar) $94,4 \%$, met deze combinatie en eenzijdig spuiten van de buitenste bomenrij is een driftreductie gevonden van 93,3\% en met eenzijdig spuiten van de buitenste bomenrij met deze combinatie met gebruikmaken van automatische hoekverdraaiing van de spuitmonden met H.S.S. AWC (Automatic Wind Control) is een driftreductie van 92,1\% gevonden.

Automatische hoekverdraaiing van de spuitmonden geeft bij de HSS-CF minder drift ten opzichte van de andere instellingen. Mogelijk kan de drift verder verminderd worden door verder optimaliseren van deze techniek. 


\section{Literatuur}

CIW, 2003. Beoordelingsmethodiek emissiereducerende maatregelen Lozingenbesluit open teelt en veehouderij. Commissie Integraal Waterbeheer, Ministerie van Verkeer en Waterstaat, Werkgroep 4 Water en Milieu, Den Haag. 82 pp.

Ctgb, 2016. Evaluation Manual for the Authorisation of Plant protection products and Biocides according to Regulation (EC) No 1107/2009 NL part Plant protection products. Chapter 6 Fate and behaviour in the environment: behaviour in surface water and sediment version 2.1; October 2016. http://www.ctgb.nl/

EZ, 2013. Gezonde Groei, Duurzame Oogst. Tweede nota duurzame gewasbescherming, periode 2013 tot 2023. Ministerie van Economische Zaken, Den Haag. 2013. 46p.

Huijsmans, J.F.M., H.A.J. Porskamp \& J.C. van de Zande, 1997. Drift(beperking) bij de toediening van gewasbeschermingsmiddelen. Evaluatie van de drift van spuitvloeistof bij bespuitingen in de fruitteelt, de volveldsteelten en de boomteelt (stand van zaken december 1996). IMAG-DLO Rapport 97-04, IMAG, Wageningen, 38 pp.

I\&M, 2012. Activiteitenbesluit Milieubeheer, Staatsblad 2012 441/643

ISO 22866, 2005. Equipment for crop protection - Methods for the field measurement of spray drift. International Standardisation Organisation, Geneva. 2005.

ISO-22369, 2006. Crop protection equipment - Drift classification of spraying equipment. Part 1. Classes. International Standardisation Organisation, Geneva.

LNV, 1998. Wijziging Regeling uitvoering milieutoelatingseisen bestrijdingsmiddelen. Staatscourant $153,1998$.

LNV, 2004. Duurzame gewasbescherming. Gewasbeschermingsbeleid naar 2010. Ministerie van Landbouw, Natuur en Visserij, Den Haag. 2004. 44p.

Michielsen, J.M.G.P., Wenneker, M., Zande, J.C. van de \& Heijne, B., 2007. Contribution of individual row sprayings to airborne drift spraying an apple orchard. In: E. Gil, F. Solanelles, S. Planas, J.R. Rossell \& L. Val (eds). 8th Workshop on Spray Application Techniques in Fruit Growing June 2005 Barcelona, Book of Abstracts, Universitat Politècnica de Catalunya, Generalitat de Catalunya, Universitat de Lleida, Barcelona, 2007. p.37-46

MJPG, 1991. Regeringsbeslissing Meerjarenplan Gewasbescherming 21667, nrs 3-4, 298 pp.

Payne et al., 2006. Genstat Release 9.2,

Stallinga, H., J.C. van de Zande, M. Wenneker, J.M.G.P. Michielsen, P. van Velde, N. Joosten, 2011 a. Doppenclassificatie fruitteelt. Driftmetingen van driftreducerende spuitdoppen bij enkelzijdig bespuiten van de buitenste bomenrij in de volblad situatie, Veldmetingen 2008-2009. Wageningen UR Praktijkonderzoek Plant en Omgeving / Plant Research International, PPO/PRI Rapport 366, Wageningen, 2011. 36pp.

Stallinga, H., J.C. van de Zande, M. Wenneker, J.M.G.P. Michielsen, P. van Velde, N. Joosten, 2011 b. Doppenclassificatie fruitteelt. Driftmetingen klassengrensdoppen, Veldmetingen 2008-2009. Wageningen UR Praktijkonderzoek Plant en Omgeving / Plant Research International, PPO/PRI Rapport 365, Wageningen, 2011. 66pp.

Stallinga, H., M. Wenneker, J.C. van de Zande, J.M.G.P. Michielsen, P. van Velde, A.T. Nieuwenhuizen \& L.L.P. Luckerhoff, 2013. Drift en driftreductie van de innovatieve drierijige emissiearme fruitteeltspuit van KWH. Wageningen UR Plant Research International, Plant Research International Rapport 458, Wageningen. 2013. 92 p.

TCT, 2016. Lijst beoordeelde technieken volgens Beoordelingsmethodiek emissiebeperkende maatregelen Activiteitenbesluit Milieubeheer. Internetsite: https://www.helpdeskwater.nl/onderwerpen/emissiebeheer/agrarisch/open-teelt/driftarmedoppen/@3575/lijst-driftarme/

VW, VROM, LNV, VWS \& SZW, 2000. Lozingenbesluit open teelt en veehouderij. Staatsblad 200043 , $117 p p$.

VW, VROM, LNV, 2007. Wijziging van het Lozingenbesluit open teelt en veehouderij en enige andere besluiten (actualisering lozingenvoorschriften). Staatsblad 2007 143, 35p. 
Wenneker, M., B. Heijne \& J.C. van de Zande, 2004. Invloed venturi-spleetdoppen en luchtondersteuning op emissies bij bespuitingen in de fruitteelt. Praktijkonderzoek Plant \& Omgeving, sector Fruit, PPO-fruit Rapport 2004-03, Randwijk, 2004.

Wenneker, M., Michielsen, J.M.G.P., Heijne, B. \& Zande, J.C. van de, 2007. Contribution of individual row sprayings to total spray drift deposition next to an apple orchard. In: E. Gil, F. Solanelles, S. Planas, J.R. Rossell \& L. Val (eds). Proceedings of the 8th Workshop on Spray Application Techniques in Fruit Growing, June 2005 Barcelona, Universitat Politècnica de Catalunya, Generalitat de Catalunya, Universitat de Lleida, Barcelona, 2007. p.57-64

Wenneker, M., J.C. van de Zande, H. Stallinga, J.M.G.P. Michielsen, P. van Velde \& A.T. Nieuwenhuizen, 2014. Emission reduction in orchards by improved spray deposition and increased spray drift reduction of multiple row sprayers. International Advances in Pesticide Application, Aspects of Applied Biology 122, 2014. p. 195-202

Zande, J.C. van de, B. Heijne \& M. Wenneker, 2001. Driftreductie bij bespuitingen in de fruitteelt (stand van zaken december 2001). Instituut voor Milieu- en Agritechniek, IMAG Rapport 2001-19, Wageningen. 36pp.

Zande, J.C. van de, H.J. Holterman \& M. Wenneker, 2007. Doppenclassificatie fruitteelt. Vaststellen referentie spuitdoppen klassengrenzen. Wageningen UR, Plant Research International, WUR-PRI Report 150, Wageningen. 2007. 22 p.

Zande, J.C. van de, M. Wenneker, J.M.G.P. Michielsen, H. Stallinga, P. van Velde \& N. Joosten, 2012. Nozzle classification for drift reduction in orchard spraying. International Advances in Pesticide Application. Aspects of Applied Biology 114. p. 253-260

Zande, J.C. van de, M.C. Butler Ellis, M. Wenneker, P J Walklate \& M. Kennedy, 2014. Spray drift and bystander risk from fruit crop spraying. International Advances in Pesticide Application, Aspects of Applied Biology 122, 2014. p. 177-186 


\section{Bijlage 1 Script statistische analyse}

IRREML

[PRINT =MOD,COM,MEAN,EFF,WALD,DEV;

$\mathrm{DISTR}=\mathrm{BIN} ; \mathrm{LINK}=\mathrm{LOGIT} ; \mathrm{DISP}=*$;

RANDOM $=$ hh $*$ rij; $\backslash$

FIXED = techniek; $\backslash$

$\mathrm{PSE}=\mathrm{ALLD} ; \mathrm{CHECK}=\mathrm{YES} ;$ meth=fisher] zone; $\mathrm{NBIN}=100 ; \backslash$

RESID = Rest; FITTED = zoneFIT 


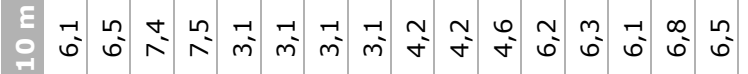

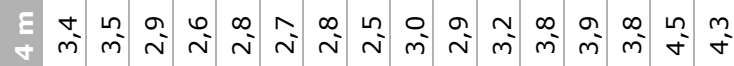

$\frac{8}{0}$
$\frac{0}{0}$
$\frac{1}{0}$
$\frac{0}{0}$
$\frac{5}{0}$
$\frac{0}{0}$
$\frac{0}{3}$

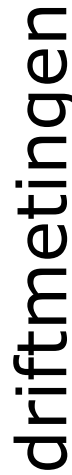

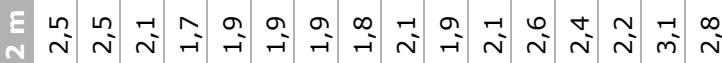

E

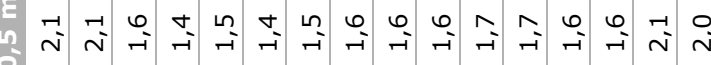

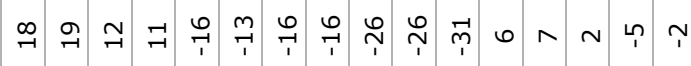

$\frac{n}{0}$

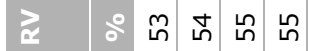

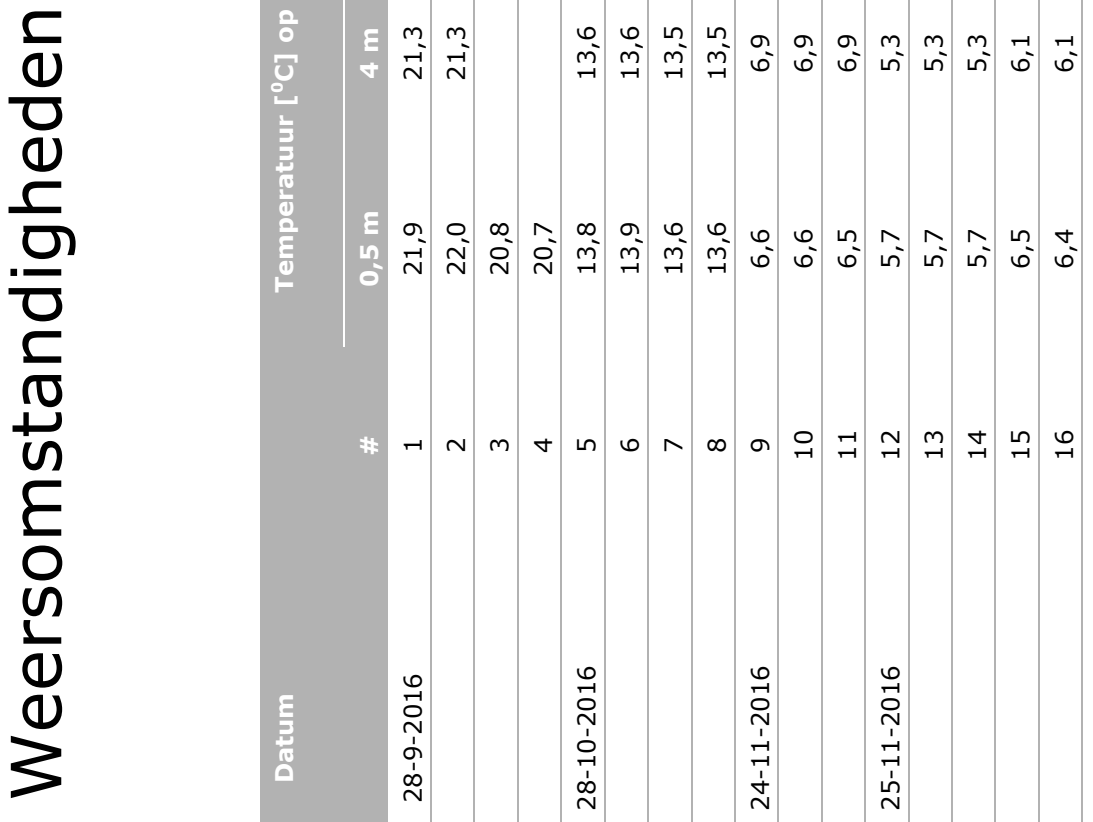

N

U

$\frac{\pi}{n}$ 


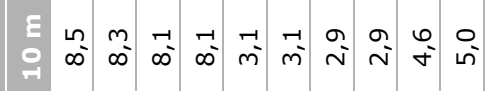

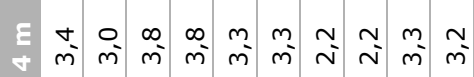

$\frac{8}{0}$
$\frac{0}{n}$
$\frac{3}{0}$
$\frac{0}{0}$
$\frac{5}{0}$
$\frac{0}{0}$
$\frac{5}{3}$

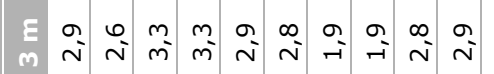

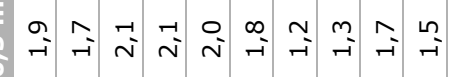

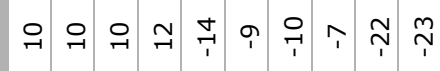

$\infty \infty$

$\stackrel{2}{2}$

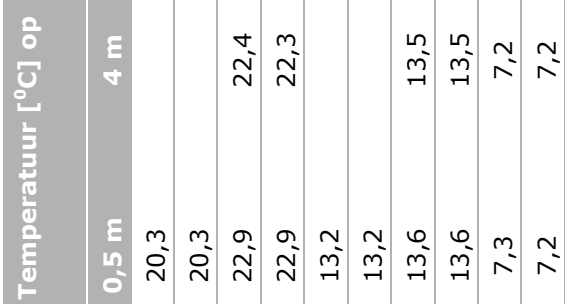

\#H n

E

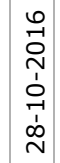

0
$\stackrel{1}{1}$
1

$\stackrel{1}{N}$

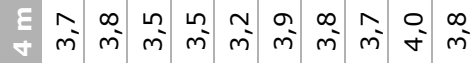

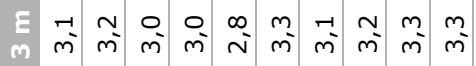

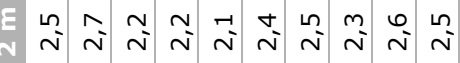

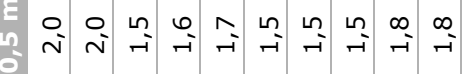

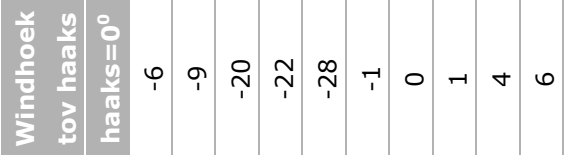

दे \&

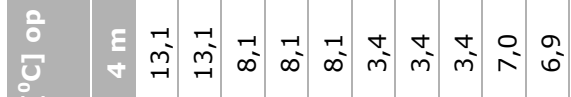

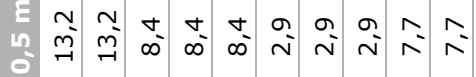

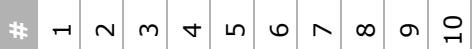

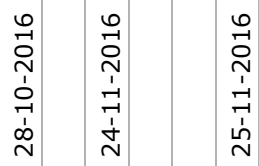




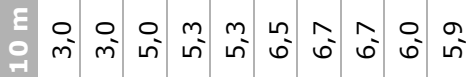

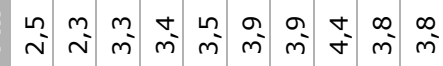

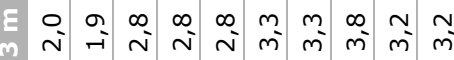

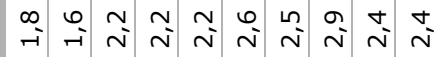

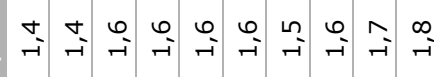

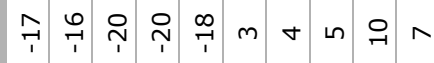

के

$\vec{x}$

ชิ ชุด ช

f)

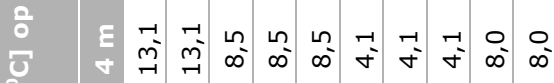

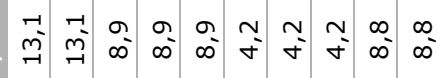

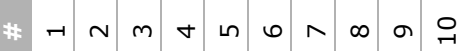

ह

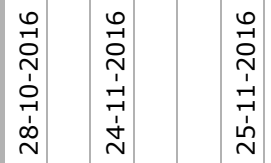

1
1
0

$u$
1
$u$
$u$
$\dot{1}$
0
I 


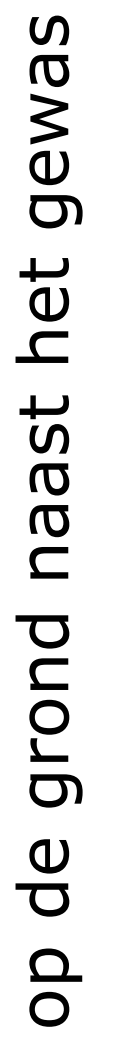

高

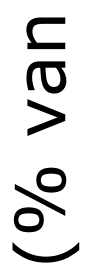

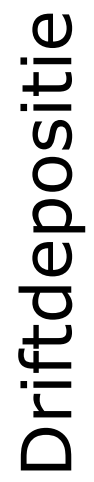

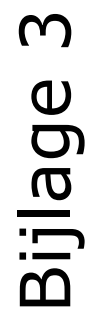

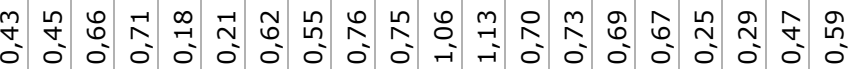
กิ

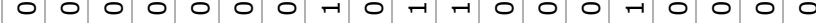

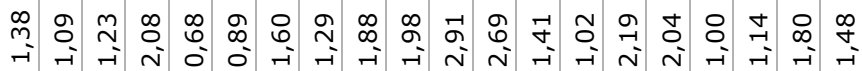

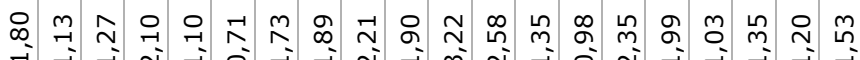

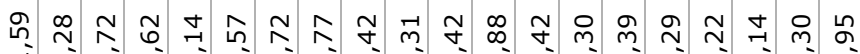
r i i fi б워

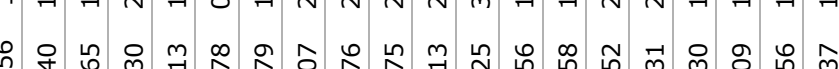

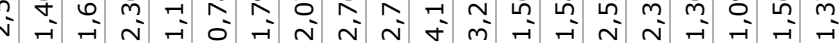

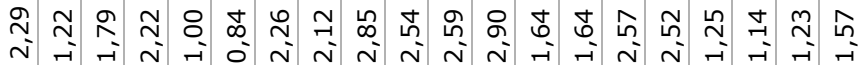
㣜

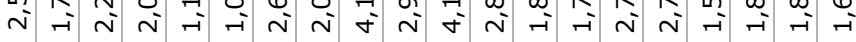

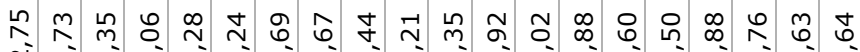
人

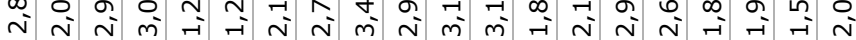
ザ

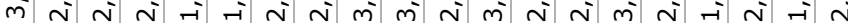

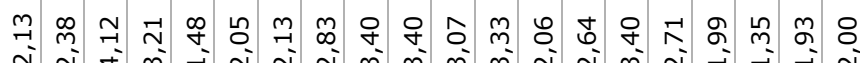

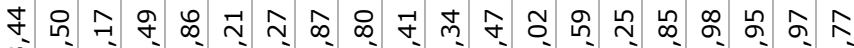

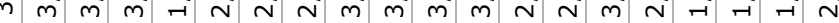

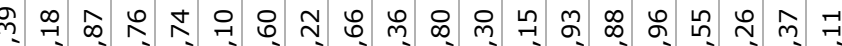

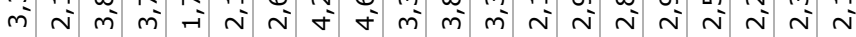

च/8-8

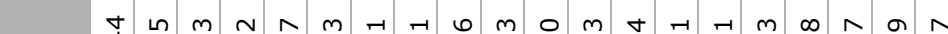

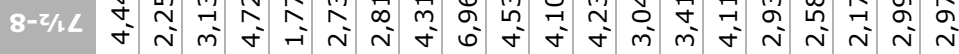

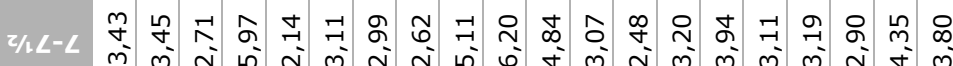
L-z/19

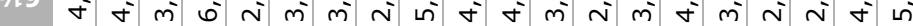

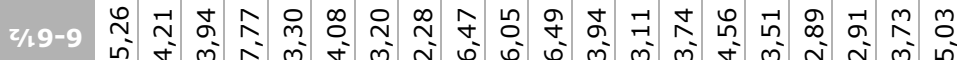

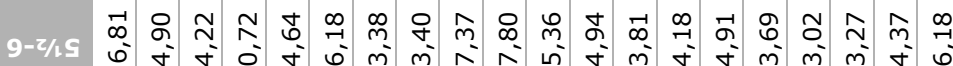
च/,9-c

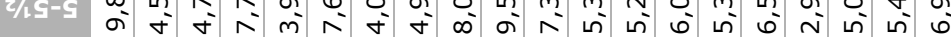

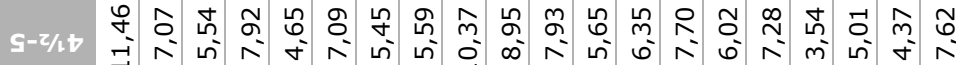

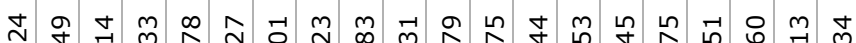
穴 苟

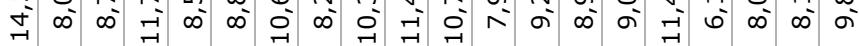
눙 ঢ

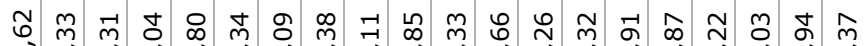

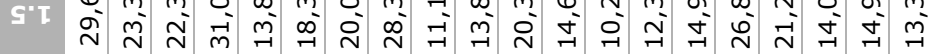

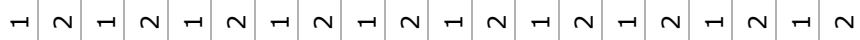




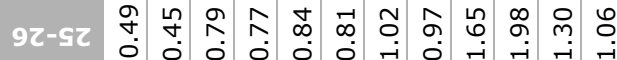

$12-0 Z$

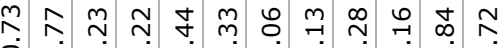

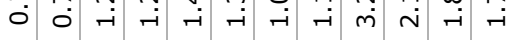

$S T-2 / L T+$ ?ִ

$\tau / 1+I-t)$

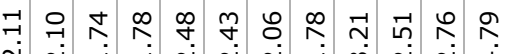

$\rightarrow T-\tau / 1 \varepsilon I$

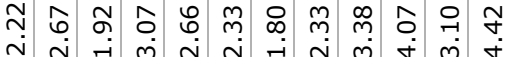

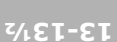

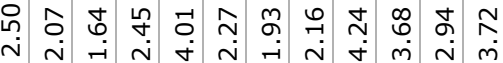

$\varepsilon T-z / 1 \zeta T$ ஒீ

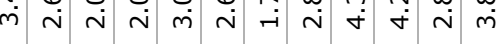

z/८LT-ZT ก

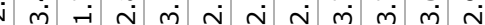

$2 \mathrm{I}-2 / \mathrm{LIT}$

ஸી

T/LIT-IT

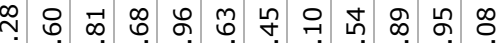

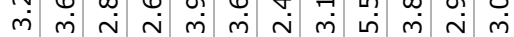

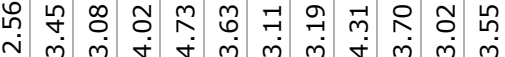
ঢำ

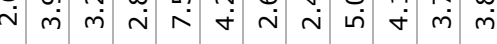

$0 \pi-2 / 16$

2/16-6

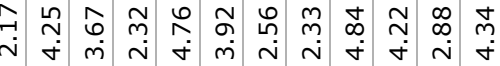
$\stackrel{m}{\stackrel{n}{r}}$ ○

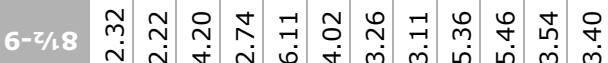

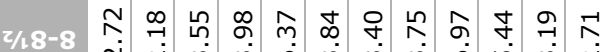

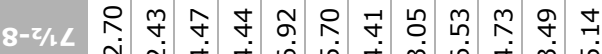

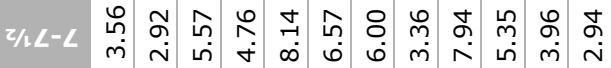

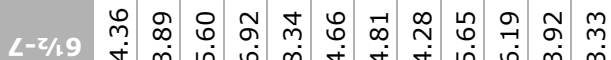

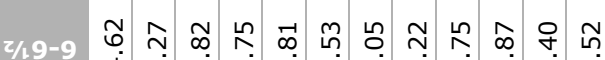

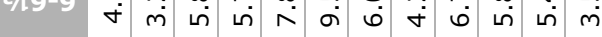

$9-2 / 19$ g.

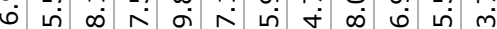

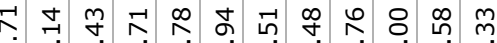
ம் ம் பீ. $s-z / 1, t$

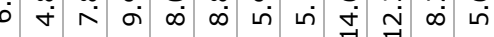

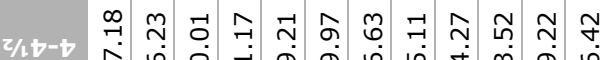

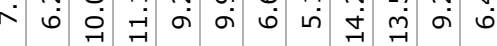
กी

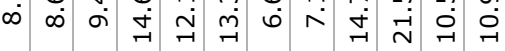
ㄴ. 어 0 어 o 걱 స

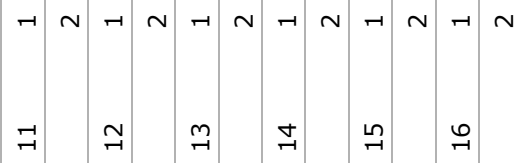




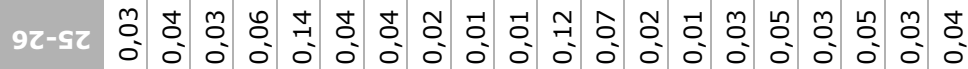

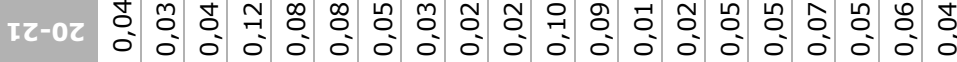

$s t-z / \Delta t$

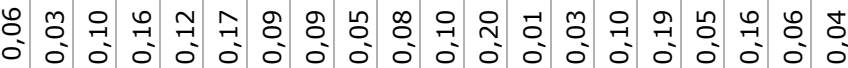

$2 / 4 t \pi-t)$

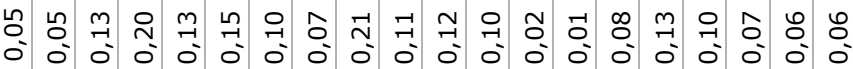

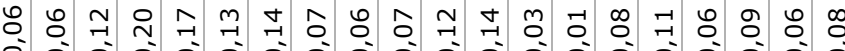

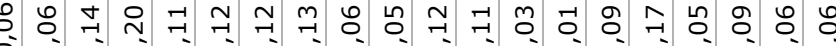

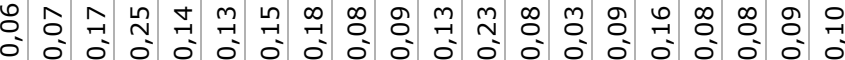

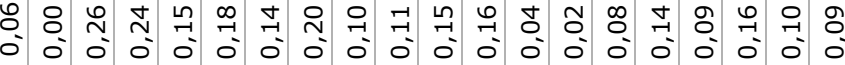

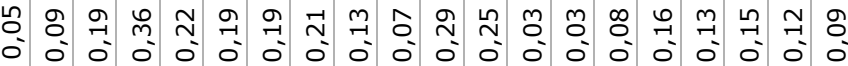

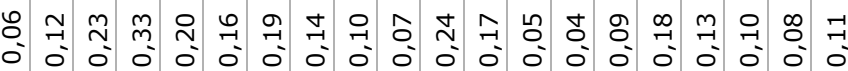
국 규

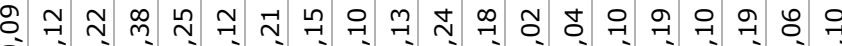

$0 \pi-\pi 6$ g J

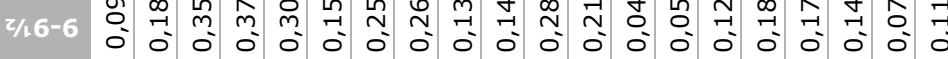

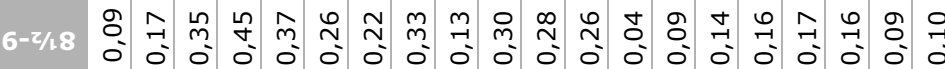

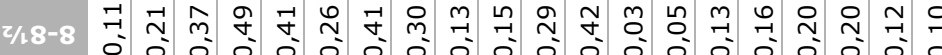
$8-z / 1 L$ 근

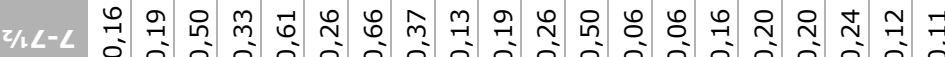

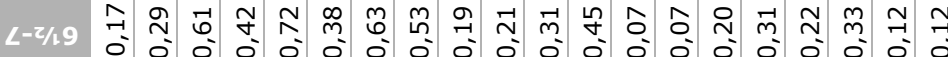

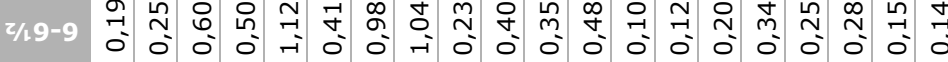

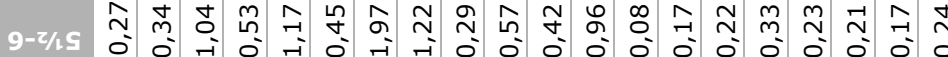

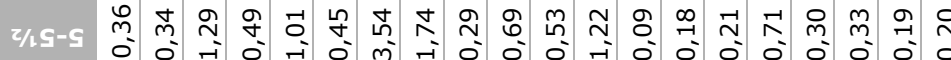

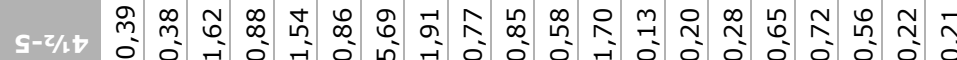

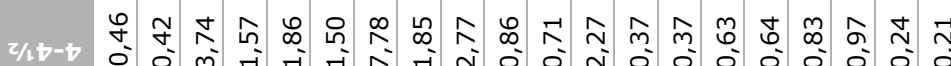
นี

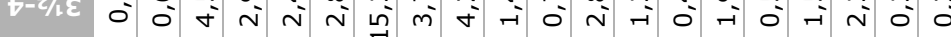

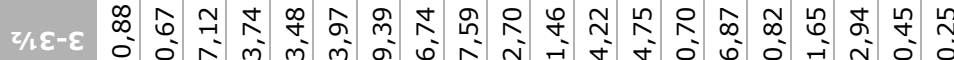
ए

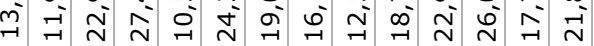
กั

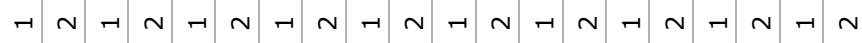




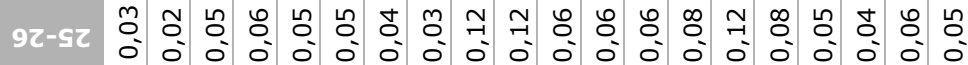

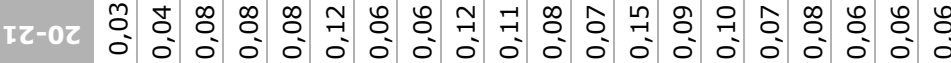

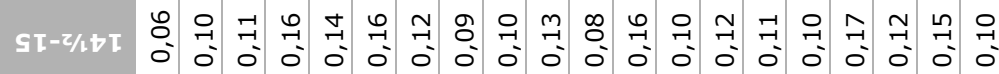

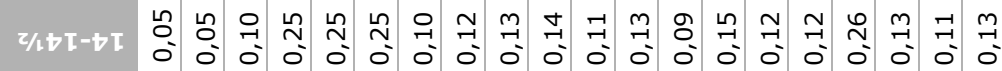

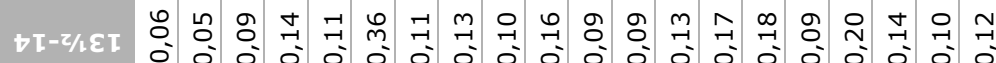

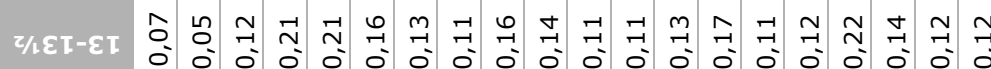

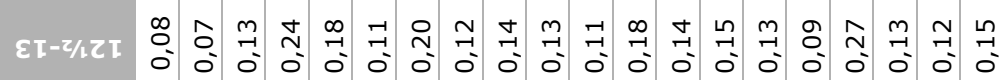

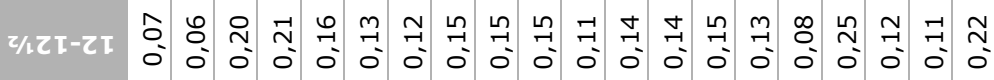

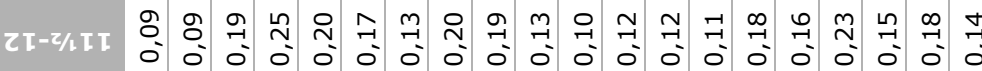

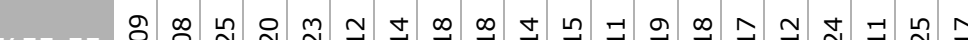

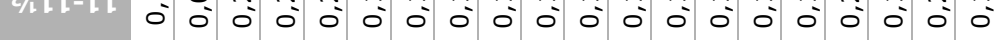

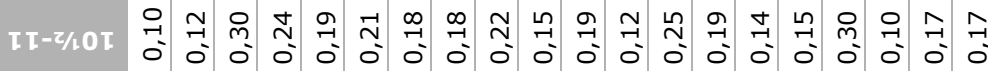

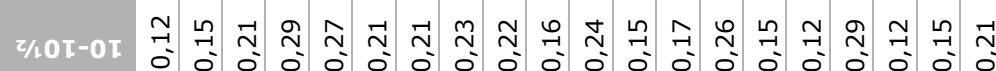

$0 \pi-z / 16$ 궁 공

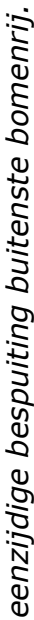

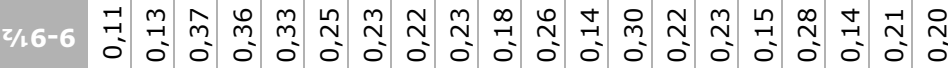

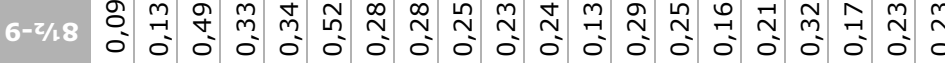

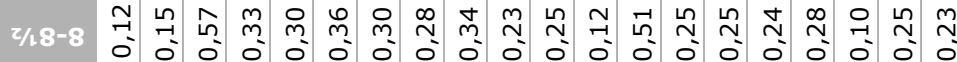

8-z/LL 눈

J

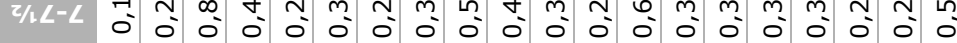

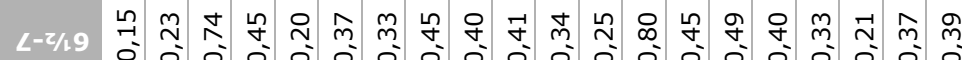

य/19-9

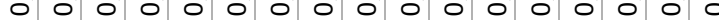

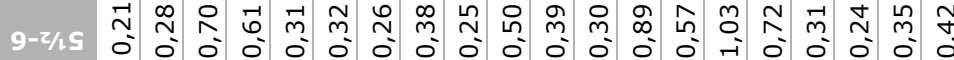

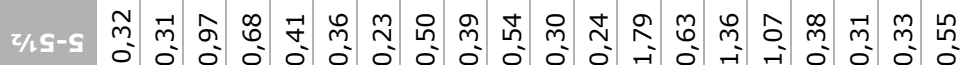

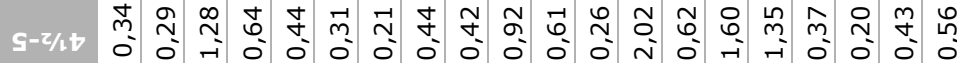

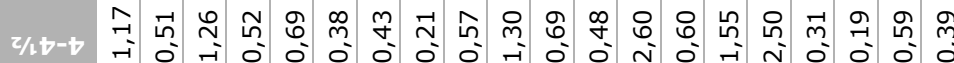

$\stackrel{\infty}{\infty}$

trif $g$ 守

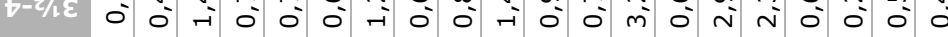

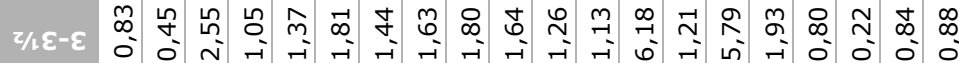

㭊

ज़

I

苟

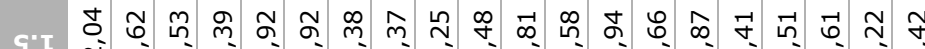

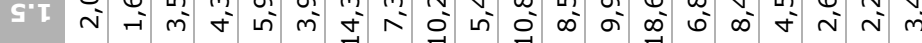




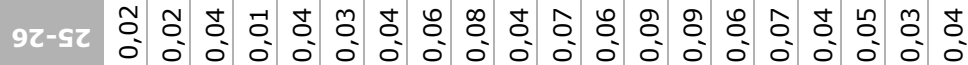

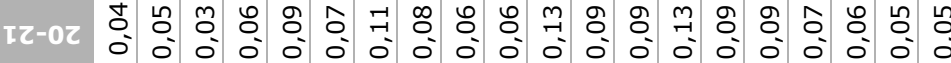

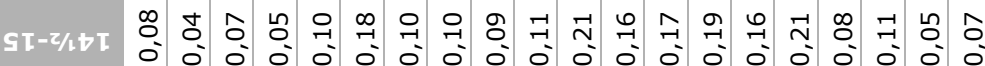

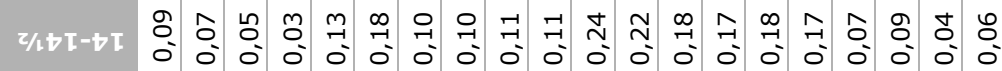

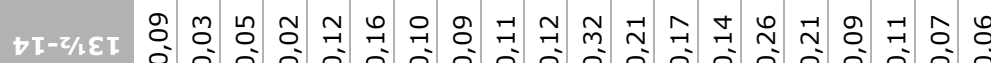

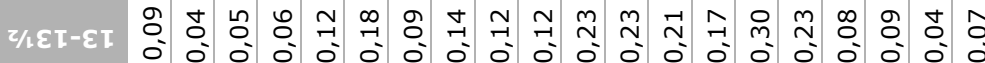

(5)

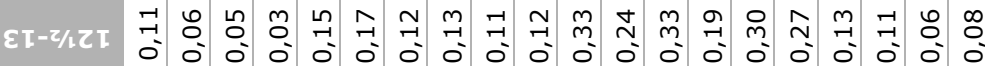

2/2T-ZT

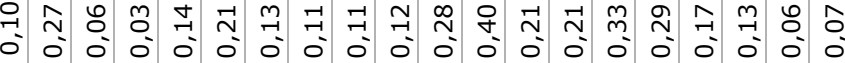

$\tau \pi-2 / 2 \pi$

웡 0 t

$2 / 1 \tau-\tau T$

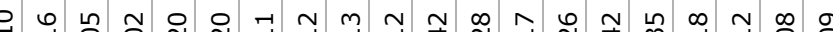

$\tau \tau-2 / 10 \tau$

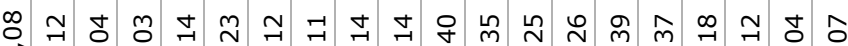

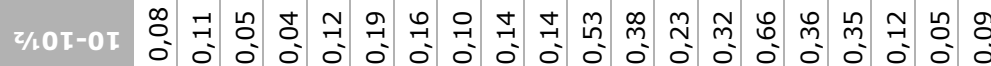

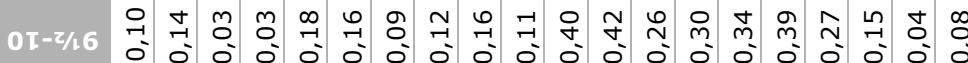

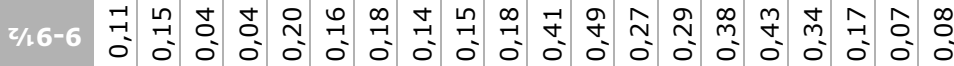

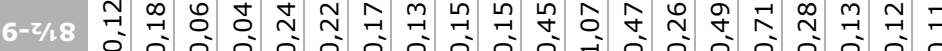

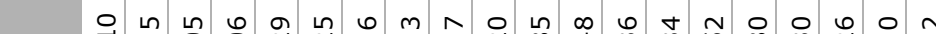

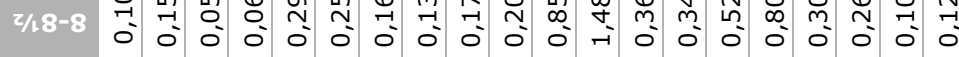

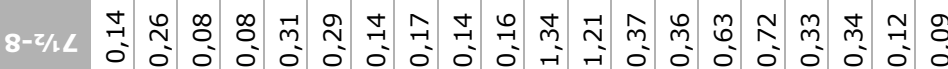

m

L-z:0

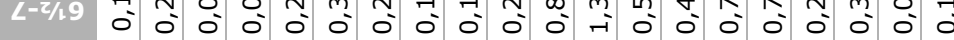

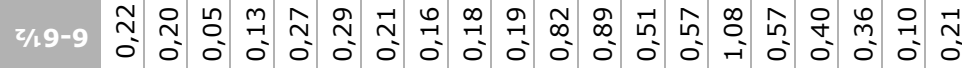

$0-z / c$ స

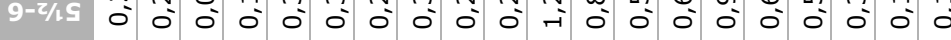

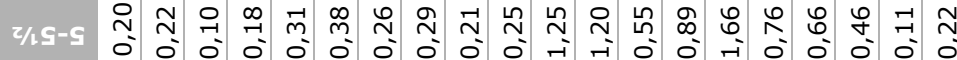

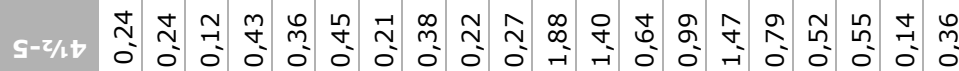

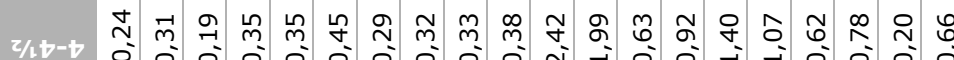

8े

$\stackrel{\infty}{\lessgtr}$

the

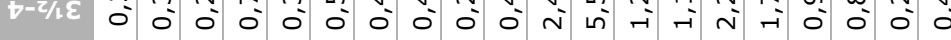

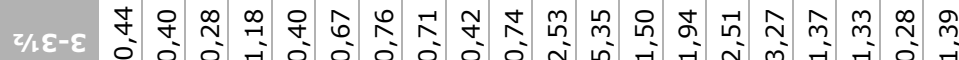

ह

药

ज̂̀

I

苟

ㄴ.

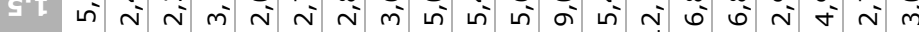

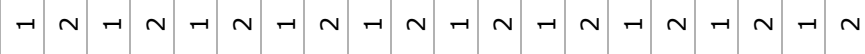




\section{Bijlage 4 Driftdepositie (\% van afgifte) naar de lucht}

Techniek: Standaard dwarsstroom fruitteeltspuit (Munckhof) met ATR Lila spuitdoppen.

\begin{tabular}{|c|c|c|c|c|c|c|c|c|c|c|c|c|}
\hline \multirow[b]{2}{*}{$\#$} & \multirow[b]{2}{*}{ Rij } & \multicolumn{11}{|c|}{$\%$ drift op hoogte $(\mathrm{m})$} \\
\hline & & 0 & 1 & 2 & 3 & 4 & 5 & 6 & 7 & 8 & 9 & 10 \\
\hline \multirow[t]{2}{*}{1} & 1 & 5,82 & 15,50 & 12,71 & 11,30 & 7,83 & 6,96 & 4,59 & 2,59 & 2,17 & 1,60 & 1,23 \\
\hline & 2 & 6,67 & 17,02 & 14,76 & 13,36 & 10,70 & 5,75 & 4,10 & 3,54 & 1,39 & 1,58 & 1,10 \\
\hline \multirow[t]{2}{*}{2} & 1 & 5,93 & 13,86 & 13,25 & 9,65 & 11,09 & 7,36 & 4,42 & 2,29 & 1,52 & 0,38 & 0,25 \\
\hline & 2 & 4,19 & 12,97 & 12,57 & 10,53 & 7,02 & 4,10 & 4,85 & 2,13 & 1,06 & 0,34 & 0,26 \\
\hline \multirow[t]{2}{*}{3} & 1 & 5,55 & 5,16 & 5,31 & 6,97 & 5,51 & 4,03 & 1,62 & 1,09 & 0,37 & 0,63 & 0,18 \\
\hline & 2 & 4,32 & 4,28 & 5,65 & 7,10 & 3,77 & 3,60 & 2,82 & 1,22 & 0,57 & 0,46 & 0,13 \\
\hline \multirow[t]{2}{*}{4} & 1 & 4,70 & 5,93 & 8,38 & 5,58 & 9,05 & 8,27 & 3,72 & 1,39 & 1,49 & 0,87 & 0,67 \\
\hline & 2 & 4,81 & 6,03 & 9,99 & 12,70 & 10,95 & 8,50 & 3,82 & 3,03 & 1,09 & 0,47 & 0,47 \\
\hline \multirow[t]{2}{*}{5} & 1 & 7,80 & 10,09 & 10,82 & 15,41 & 10,55 & 8,11 & 3,58 & 2,71 & 1,61 & 0,82 & 0,93 \\
\hline & 2 & 7,08 & 6,99 & 8,29 & 12,88 & 9,59 & 6,15 & 5,13 & 3,44 & 1,73 & 0,77 & 0,59 \\
\hline \multirow[t]{2}{*}{6} & 1 & 5,21 & 7,91 & 6,04 & 10,06 & 8,87 & 5,49 & 3,64 & 1,64 & 0,93 & 1,09 & 0,69 \\
\hline & 2 & 5,15 & 7,08 & 7,51 & 11,61 & 15,69 & 8,15 & 4,18 & 1,83 & 1,28 & 0,92 & 0,44 \\
\hline \multirow[t]{2}{*}{7} & 1 & 4,64 & 8,59 & 12,74 & 11,60 & 4,83 & 4,73 & 2,16 & 1,19 & 0,67 & 0,52 & 0,20 \\
\hline & 2 & 5,47 & 8,62 & 9,60 & 11,86 & 7,89 & 5,98 & 3,82 & 1,76 & 0,63 & 0,35 & 0,28 \\
\hline \multirow[t]{2}{*}{8} & 1 & 5,44 & 5,72 & 10,07 & 12,37 & 10,85 & 5,58 & 2,87 & 2,41 & 1,46 & 0,97 & 1,53 \\
\hline & 2 & 4,14 & 7,70 & 12,49 & 10,61 & 9,84 & 5,53 & 4,37 & 2,33 & 1,46 & 1,87 & 1,34 \\
\hline \multirow[t]{2}{*}{9} & 1 & 3,08 & 5,43 & 7,58 & 8,40 & 3,92 & 4,82 & 4,52 & 4,63 & 3,91 & 3,28 & 2,22 \\
\hline & 2 & 2,43 & 7,31 & 5,42 & 8,18 & 6,86 & 5,32 & 4,49 & 3,85 & 3,24 & 2,92 & 2,38 \\
\hline \multirow[t]{2}{*}{10} & 1 & 2,93 & 6,71 & 4,41 & 5,20 & 4,65 & 4,03 & 2,66 & 2,30 & 2,37 & 1,40 & 1,06 \\
\hline & 2 & 3,41 & 5,26 & 5,07 & 4,73 & 4,47 & 3,36 & 2,63 & 2,67 & 1,83 & 1,02 & 0,79 \\
\hline \multirow[t]{2}{*}{11} & 1 & 4,36 & 7,04 & 4,34 & 8,00 & 5,73 & 6,89 & 2,80 & 2,33 & 1,93 & 1,26 & 1,09 \\
\hline & 2 & 3,05 & 5,17 & 5,61 & 5,25 & 6,90 & 6,67 & 3,17 & 1,98 & 1,37 & 1,71 & 0,80 \\
\hline \multirow[t]{2}{*}{12} & 1 & 7,99 & 9,90 & 9,30 & 17,16 & 12,35 & 7,62 & 5,27 & 2,20 & 2,05 & 1,52 & 0,99 \\
\hline & 2 & 9,68 & 15,99 & 17,61 & 15,20 & 13,83 & 8,98 & 5,32 & 3,53 & 2,22 & 1,34 & 1,21 \\
\hline \multirow[t]{2}{*}{13} & 1 & 9,23 & 13,05 & 13,20 & 14,87 & 15,21 & 10,48 & 6,19 & 4,39 & 2,42 & 2,19 & 0,81 \\
\hline & 2 & 8,31 & 13,76 & 18,67 & 16,50 & 16,97 & 8,47 & 3,54 & 2,52 & 2,39 & 1,29 & 0,18 \\
\hline \multirow[t]{2}{*}{14} & 1 & 7,62 & 8,82 & 13,67 & 12,04 & 9,92 & 4,71 & 3,40 & 3,01 & 2,24 & 0,90 & 0,49 \\
\hline & 2 & 6,23 & 9,32 & 11,18 & 11,97 & 11,83 & 5,37 & 4,92 & 2,53 & 1,88 & 1,22 & 0,99 \\
\hline \multirow[t]{2}{*}{15} & 1 & 13,33 & 12,16 & 17,31 & 16,46 & 13,44 & 9,91 & 8,05 & 5,16 & 3,99 & 2,02 & 1,73 \\
\hline & 2 & 12,27 & 16,75 & 16,82 & 14,80 & 18,60 & 11,53 & 11,38 & 6,69 & 3,62 & 1,71 & 1,61 \\
\hline \multirow[t]{2}{*}{16} & 1 & 6,67 & 12,61 & 18,41 & 16,89 & 12,05 & 9,98 & 7,96 & 4,83 & 2,41 & 1,81 & 1,27 \\
\hline & 2 & 8,09 & 19,13 & 14,20 & 18,55 & 15,91 & 9,15 & 6,70 & 3,35 & 2,57 & 1,19 & 0,85 \\
\hline
\end{tabular}


Techniek: HSS-CF met TVI8001 venturi werveldoppen en tweezijdige bespuiting buitenste bomenrij.

\begin{tabular}{|c|c|c|c|c|c|c|c|c|c|c|c|c|}
\hline \multirow[b]{2}{*}{ \# } & \multirow[b]{2}{*}{ Rij } & \multicolumn{11}{|c|}{$\%$ drift op hoogte $(\mathrm{m})$} \\
\hline & & 0 & 1 & 2 & 3 & 4 & 5 & 6 & 7 & 8 & 9 & 10 \\
\hline 1 & 1 & 0,33 & 0,33 & 0,34 & 0,28 & 0,20 & 0,16 & 0,10 & 0,04 & $<0,01$ & $<0,01$ & $<0,01$ \\
\hline \multirow[t]{2}{*}{2} & 1 & 0,33 & 0,86 & 0,60 & 0,35 & 0,39 & 0,27 & 0,14 & 0,15 & 0,07 & $<0,01$ & 0,02 \\
\hline & 2 & 0,28 & 0,59 & 0,73 & 0,69 & 0,45 & 0,22 & 0,19 & 0,08 & 0,06 & $<0,01$ & 0,02 \\
\hline 3 & 2 & 0,66 & 0,68 & 0,67 & 0,77 & 0,51 & 0,47 & 0,23 & 0,12 & 0,07 & 0,01 & 0,04 \\
\hline \multirow[t]{2}{*}{4} & 1 & 0,81 & 0,74 & 0,80 & 0,51 & 0,37 & 0,28 & 0,19 & 0,07 & 0,08 & 0,02 & $<0,01$ \\
\hline & 2 & 0,58 & 0,83 & 0,69 & 1,01 & 0,29 & 0,22 & 0,17 & 0,13 & 0,08 & 0,05 & 0,01 \\
\hline 5 & 1 & 0,31 & 0,41 & 0,38 & 0,35 & 0,20 & 0,15 & 0,28 & 0,12 & 0,07 & 0,07 & $<0,01$ \\
\hline \multirow[t]{2}{*}{7} & 1 & 0,15 & 0,13 & 0,15 & 0,06 & 0,15 & 0,07 & 0,04 & 0,06 & 0,03 & $<0,01$ & 0,02 \\
\hline & 2 & 0,15 & 0,30 & 0,22 & 0,16 & 0,11 & 0,10 & 0,08 & $<0,01$ & $<0,01$ & $<0,01$ & 0,02 \\
\hline \multirow[t]{2}{*}{8} & 1 & 0,33 & 0,34 & 0,38 & 0,34 & 0,39 & 0,57 & 0,23 & 0,13 & $<0,01$ & 0,01 & 0,02 \\
\hline & 2 & 0,24 & 0,37 & 0,34 & 0,37 & 0,81 & 0,39 & 0,31 & 0,05 & 0,01 & $<0,01$ & 0,03 \\
\hline \multirow[t]{2}{*}{9} & 1 & 0,39 & 0,44 & 0,46 & 0,60 & 0,38 & 0,30 & 0,19 & 0,05 & $<0,01$ & $<0,01$ & 0,07 \\
\hline & 2 & 0,51 & 0,96 & 0,40 & 0,35 & 0,49 & 0,40 & 0,21 & 0,12 & 0,09 & 0,07 & 0,03 \\
\hline \multirow[t]{2}{*}{10} & 1 & 0,53 & 0,60 & 0,34 & 0,43 & 0,47 & 0,30 & 0,43 & 0,21 & 0,16 & 0,43 & 0,18 \\
\hline & 2 & 0,19 & 0,18 & 0,40 & 0,71 & 0,38 & 0,39 & 0,20 & 0,20 & 0,10 & 0,11 & 0,15 \\
\hline
\end{tabular}

Techniek: HSS-CF met TVI8001 venturi werveldoppen en eenzijdige bespuiting buitenste bomenrij.

\begin{tabular}{|c|c|c|c|c|c|c|c|c|c|c|c|c|}
\hline \multirow[b]{2}{*}{ \# } & \multirow[b]{2}{*}{ Rij } & \multicolumn{11}{|c|}{$\%$ drift op hoogte $(\mathrm{m})$} \\
\hline & & 0 & 1 & 2 & 3 & 4 & 5 & 6 & 7 & 8 & 9 & 10 \\
\hline 1 & 1 & 0,12 & 0,28 & 0,32 & 0,21 & 0,26 & 0,21 & 0,14 & 0,14 & 0,12 & 0,02 & 0,07 \\
\hline \multirow[t]{2}{*}{2} & 1 & 0,62 & 0,87 & 0,83 & 0,69 & 0,40 & 0,19 & 0,09 & 0,10 & 0,03 & 0,06 & 0,01 \\
\hline & 2 & 0,62 & 1,12 & 0,97 & 1,06 & 0,41 & 0,20 & 0,15 & 0,14 & 0,09 & 0,12 & $<0,01$ \\
\hline 3 & 2 & 0,69 & 0,53 & 0,53 & 0,63 & 1,02 & 0,63 & 0,38 & 0,31 & 0,35 & 0,19 & 0,15 \\
\hline \multirow[t]{2}{*}{4} & 1 & 0,35 & 0,68 & 0,41 & 0,48 & 0,45 & 0,23 & 0,29 & 0,09 & 0,03 & $<0,01$ & 0,03 \\
\hline & 2 & 0,47 & 0,95 & 0,60 & 0,79 & 0,64 & 0,48 & 0,38 & 0,14 & 0,08 & 0,05 & $-0,01$ \\
\hline 5 & 1 & 0,59 & 1,33 & 0,91 & 0,73 & 0,63 & 0,46 & 0,34 & 0,22 & 0,43 & 0,25 & 0,25 \\
\hline \multirow[t]{2}{*}{7} & 1 & 0,93 & 1,06 & 0,86 & 0,82 & 0,59 & 0,40 & 0,49 & 0,32 & 0,39 & 0,26 & 0,38 \\
\hline & 2 & 0,88 & 0,67 & 0,83 & 0,89 & 0,55 & 0,56 & 0,35 & 0,38 & 0,20 & 0,35 & 0,20 \\
\hline \multirow[t]{2}{*}{8} & 1 & 0,97 & 1,23 & 1,48 & 1,00 & 0,90 & 0,65 & 0,42 & 0,41 & 0,31 & 0,40 & 0,24 \\
\hline & 2 & 0,73 & 1,11 & 1,00 & 1,19 & 0,75 & 0,62 & 0,34 & 0,42 & 0,27 & 0,13 & 0,13 \\
\hline \multirow[t]{2}{*}{9} & 1 & 0,30 & 0,44 & 0,55 & 0,59 & 0,35 & 0,48 & 0,11 & 0,14 & 0,05 & 0,08 & 0,03 \\
\hline & 2 & 0,34 & 0,38 & 0,49 & 0,38 & 0,33 & 0,40 & 0,27 & 0,21 & 0,23 & 0,07 & 0,07 \\
\hline \multirow[t]{2}{*}{10} & 1 & 0,30 & 0,40 & 0,51 & 0,41 & 0,25 & 0,19 & 0,15 & 0,15 & 0,07 & 0,13 & 0,08 \\
\hline & 2 & 0,31 & 0,36 & 0,35 & 0,58 & 0,35 & 0,20 & 0,19 & 0,12 & 0,10 & 0,04 & 0,06 \\
\hline
\end{tabular}


Techniek: HSS-CF met TVI8001 venturi werveldoppen, eenzijdige bespuiting buitenste bomenrij en automatische blaasmondverstelling.

\begin{tabular}{|c|c|c|c|c|c|c|c|c|c|c|c|c|}
\hline \multirow[b]{2}{*}{$\#$} & \multirow[b]{2}{*}{ Rij } & \multicolumn{11}{|c|}{$\%$ drift op hoogte $(\mathrm{m})$} \\
\hline & & 0 & 1 & 2 & 3 & 4 & 5 & 6 & 7 & 8 & 9 & 10 \\
\hline \multirow[t]{2}{*}{1} & 1 & 0,20 & 0,38 & 0,43 & 0,52 & 0,09 & 0,33 & 0,05 & $<0,01$ & 0,10 & 0,03 & 0,20 \\
\hline & 2 & 0,21 & 0,20 & 0,16 & 0,15 & 0,15 & 0,19 & 0,04 & 0,06 & 0,02 & $<0,01$ & 0,03 \\
\hline \multirow[t]{2}{*}{2} & 1 & 0,06 & 0,10 & 0,21 & 0,18 & 0,15 & 0,08 & 0,08 & 0,08 & 0,05 & 0,01 & $<0,01$ \\
\hline & 2 & 0,09 & 0,16 & 0,30 & 0,39 & 0,13 & 0,08 & 0,09 & 0,03 & $<0,01$ & 0,01 & $<0,01$ \\
\hline \multirow[t]{2}{*}{3} & 1 & 0,71 & 0,63 & 0,84 & 0,87 & 0,85 & 0,45 & 1,55 & 0,85 & 0,86 & 1,17 & 0,80 \\
\hline & 2 & 0,59 & 0,40 & 0,85 & 0,87 & 0,43 & 0,41 & 0,51 & 0,24 & 0,14 & 0,13 & 0,07 \\
\hline \multirow[t]{2}{*}{4} & 1 & 0,48 & 0,66 & 0,72 & 0,95 & 1,12 & 1,23 & 1,45 & 1,05 & 0,49 & 0,77 & 0,49 \\
\hline & 2 & 0,38 & 0,81 & 0,70 & 0,64 & 1,16 & 0,82 & 0,44 & 0,49 & 0,37 & 0,24 & 0,18 \\
\hline \multirow[t]{2}{*}{5} & 1 & 0,78 & 1,50 & 0,89 & 1,39 & 1,02 & 1,10 & 0,81 & 0,94 & 0,69 & 0,37 & 0,67 \\
\hline & 2 & 0,95 & 0,88 & 0,91 & 1,29 & 1,28 & 1,35 & 1,21 & 0,91 & 0,86 & 0,29 & 0,44 \\
\hline \multirow[t]{2}{*}{6} & 1 & 0,86 & 1,68 & 1,10 & 0,87 & 0,71 & 0,75 & 0,70 & 0,48 & 0,51 & 0,43 & 0,26 \\
\hline & 2 & 0,91 & 1,61 & 1,44 & 0,93 & 1,07 & 0,73 & 0,49 & 0,31 & 0,28 & 0,22 & 0,12 \\
\hline \multirow[t]{2}{*}{7} & 1 & 0,93 & 0,86 & 1,20 & 1,15 & 0,96 & 0,76 & 0,58 & 0,66 & 0,45 & 0,37 & 0,33 \\
\hline & 2 & 0,71 & 0,89 & 0,94 & 1,18 & 0,89 & 0,73 & 0,60 & 0,46 & 0,33 & 0,13 & 0,14 \\
\hline \multirow[t]{2}{*}{8} & 1 & 1,48 & 1,69 & 1,72 & 1,42 & 1,24 & 0,78 & 0,70 & 0,49 & 0,19 & 0,28 & 0,31 \\
\hline & 2 & 1,48 & 1,30 & 2,04 & 1,17 & 1,10 & 0,75 & 0,50 & 0,28 & 0,17 & 0,12 & 0,10 \\
\hline \multirow[t]{2}{*}{9} & 1 & $*$ & $*$ & $*$ & $*$ & $*$ & $*$ & $*$ & $*$ & $*$ & $*$ & $*$ \\
\hline & 2 & $*$ & $*$ & $*$ & $*$ & $*$ & $*$ & $*$ & $*$ & $*$ & $*$ & $*$ \\
\hline \multirow[t]{2}{*}{10} & 1 & 0,19 & 0,18 & 0,31 & 0,26 & 0,32 & 0,18 & 0,15 & 0,14 & 0,05 & 0,02 & 0,01 \\
\hline & 2 & 0,17 & 0,28 & 0,48 & 0,44 & 0,35 & 0,27 & 0,23 & 0,09 & 0,04 & 0,07 & 0,02 \\
\hline
\end{tabular}




\section{Bijlage 5 Achtergrond informatie lijst TCT adviezen en driftarme spuitdoppen}

Lijst met TCT adviezen betreffende de H.S.S.-CF boomgaardspuit:

https://www.helpdeskwater.nl/onderwerpen/emissiebeheer/agrarisch/open-teelt/technische-

commissie/@4843/adviezen/

Vermelding van de H.S.S. -CF in de Lijst driftarme spuitdoppen (en technieken) - TCT:

https://www.helpdeskwater.nl/onderwerpen/emissiebeheer/agrarisch/open-teelt/driftarmedoppen/@3575/lijst-driftarme/

Website van Hol Spraying Systems te Meteren voor meer informatie:

http://www.holsprayingsystems.com/ 
Correspondentie adres voor dit rapport: Postbus 16

6700 AA Wageningen

T 0317480700

www.wur.nl/plant-research

Rapport 675
De missie van Wageningen University \& Research is 'To explore the potential of nature to improve the quality of life'. Binnen Wageningen University \& Research bundelen Wageningen University en gespecialiseerde onderzoeksinstituten van Stichting Wageningen Research hun krachten om bij te dragen aan de oplossing van belangrijke vragen in het domein van gezonde voeding en leefomgeving. Met ongeveer 30 vestigingen, 5.000 medewerkers en 10.000 studenten behoort Wageningen University \& Research wereldwijd tot de aansprekende kennisinstellingen binnen haar domein. De integrale benadering van de vraagstukken en de samenwerking tussen verschillende disciplines vormen het hart van de unieke Wageningen aanpak. 



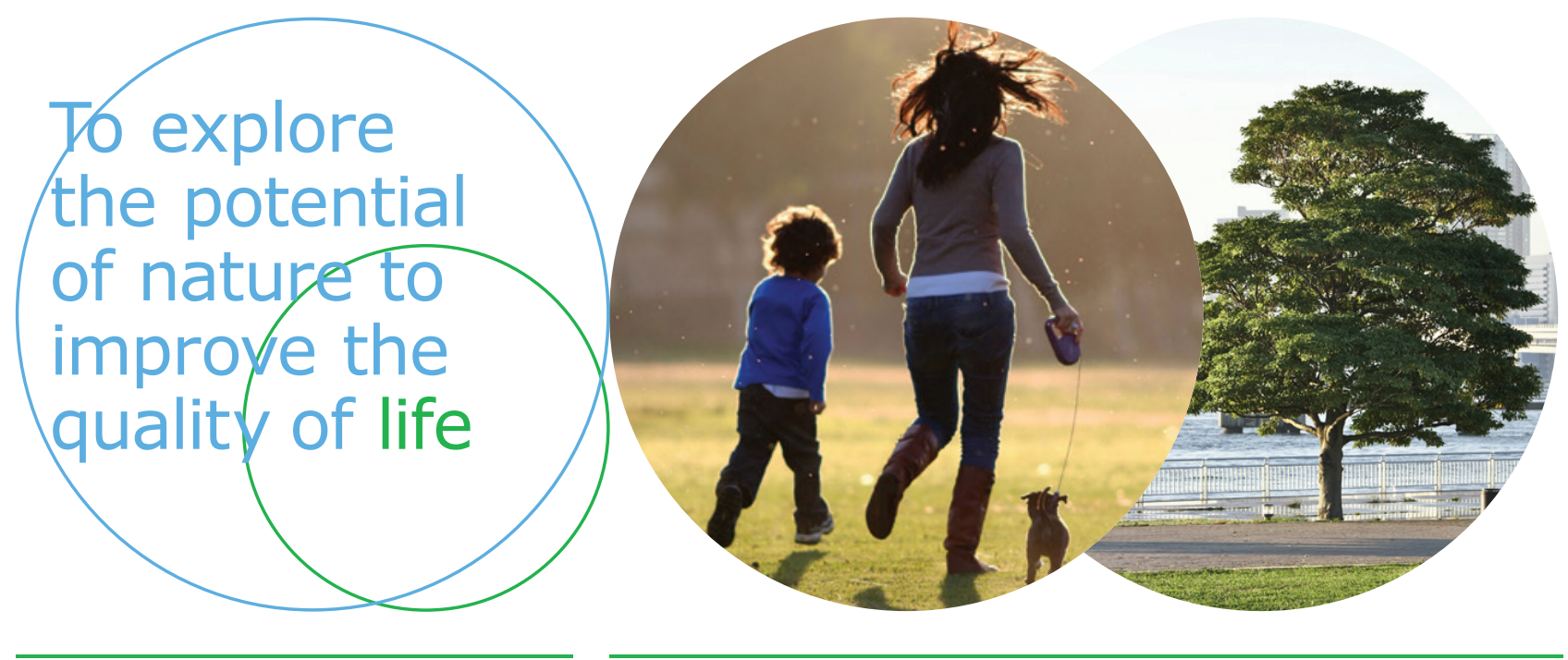

Correspondentie adres voor dit rapport: Postbus 16

6700 AA Wageningen

T 0317480700

www.wur.nl/plant-research

Rapport 675
De missie van Wageningen University \& Research is 'To explore the potential of nature to improve the quality of life'. Binnen Wageningen University \& Research bundelen Wageningen University en gespecialiseerde onderzoeksinstituten van Stichting Wageningen Research hun krachten om bij te dragen aan de oplossing van belangrijke vragen in het domein van gezonde voeding en leefomgeving. Met ongeveer 30 vestigingen, 5.000 medewerkers en 10.000 studenten behoort Wageningen University \& Research wereldwijd tot de aansprekende kennisinstellingen binnen haar domein. De integrale benadering van de vraagstukken en de samenwerking tussen verschillende disciplines vormen het hart van de unieke Wageningen aanpak. 